\title{
MARKKU KOIVUSALO
}

\section{IHMISEN KUOLEMA II}

\section{ANTIHUMANistin ESTEETTINEN POLITIIKKA}

TAITEEN RUUMIS

"Muuta maailmaa" sanoi Marx, "muuta elämää" sanoi Rimbaud, nämä kaksi käskysanaa ovat meille yksi ja sama. (André Breton: Surrealismin poliittinen asenne.)

28.9.1966 Pariisissa kuoli ihminen, joka yli puolen vuosisadan ajan oli ollut ihmisen mielen kumoamiseen pyrkineen 1900-luvun johtavan poliittis-esteettisen liikkeen ruumiillistuma. Vaikka surrealistisen liikkeen loistonpäivät olivat kaukana takanapäin, sen lopullinen hautaus näytti tapahtuvan, kun André Bretonin ruumis matkasi lokakuun ensimmäisenä vuonna 1966 Batignolles'n hautausmaalle. Esteettinen elämän kumous ei tietenkään ollut surrealismin keksintö vaan oli muodostanut 1800luvun alusta asti keskeisen modernin maailman tavoitteen. Varhaisromantiikka oli jo asettanut ihmisen esteettisen lunastuksen päämääräkseen, Ranskan vallankumouksen suorittaman kuninkaan mestauksen poliittiseksi täydentäjäksi ja valistuksen sekä varsinkin Kantin suorittaman metafysiikan ja Jumalan tietoteoreettisen mestauksen jatkoksi. Niinpä nähdessään Kantin jälkeen kaiken "metafysiikan kaatuvan tästedes moraaliin", ${ }^{1}$ Tübingenin nuoret pappisseminaarilaiset (Hegel, Hörderlin ja Schelling) halusivat vapauttaa tuon moraalin niin mekaanisen valtion kuin tekopyhien pappienkin vallasta ja etsivät uuden moraalin käytännöllisten postulaattien yhteyttä kauneuden ideasta, jonka asettava järjen korkein toimi olisi samalla esteettinen teko. Etenkin runoudesta olisi tultava taas ihmiskunnan opettaja tiellä kohti "absoluuttista kaikkien henkien vapautta. Nämä henget kantavat intellektuaalista maailmaa itsessään, eivätkä etsi sen enempää Jumalaa kuin kuolemattomuutta itsensä ulkopuolelta."2 Tuossa järjen ja sydämen monoteismin ja kuvittelukyvyn ja taiteen polyteismin yhdistävässä ihmiskunnan lunastuksessa "yhtäkään voimaa ei enää alisteta vaan vallitsee yleinen vapaiden ja tasa-arvoisten henkien herruus". 3 Myöhemmin kaunotaiteen luentojensa niin sanotussa "taiteen kuolema" -lausumassa Hegel kuitenkin totesi kuuluisaksi tulleella tavalla, että "taide korkeimman merkityksemme (bestimmung) puolena on ja pysyy menneisyytenä. Näin se on kadottanut omimman totuutensa ja elävyytensä (lebendigkeit) ja asettunut pelkäksi meidän representaatioksemme (Vorstellung)." ${ }^{4}$

"Taide on kuollut, kauan eläköön Tatlinin konetaide", 5 julisti vuorostaan Berliinin ensimmäisen kansainvälisen dada-näyttelyn juliste, kun ensimmäisen maailman- 
sodan mielettömyyden kokemuksen läpikäynyt sukupolvi ja sen uuden taiteellisen vallankumouksen etujoukko, avantgarde, otti tehtäväkseen pelkäksi representaatioksi muuttuneen ja omalakiseksi taiteeksi taiteen vuoksi eriytyneen taiteen palauttamisen elämään sen kokonaisvaltaisessa mielettömyydessä. ${ }^{6}$ Tuota tehtävää Ranskassa oli jatkanut automaattisella kirjoituksella kielelliset kokeilunsa aloittanut André Bretonin luotsaama surrealismi. Lokakuussa 1966 sadat nuoret seurasivatkin tuon surrealistisen "Kristuksen" hautajaissaattoa, "taivaaseen lähetettyä mielikuvitusta", kuten nuori Jean-Luc Nancy tuon ruumiin kunniaksi runoili.

Ruumiiden pyhitystä vastustanut Breton ei itse ollut tunnettu kuolleiden kunnioituksesta ja oli aiheuttanut nuorena kulttuuripoliittisen skandaalin jakamalla Anatole Francen kansallisissa hautajaisissa Ruumis (un cadavre) -pamflettia. ${ }^{9}$ Lentolehtinen sylki sanallisia solvauksia Ranskan kirjallisuuden ruumiillistumaksi pyhitettyä ja kolmannen tasavallan humanismia edustanutta vainajaa kohtaan, ja Breton vaati Francen heittämistä yhdessä rakkaiden kirjojensa kanssa Seinen pohjaan. "Kuolleena tuo ihminen ei saa enää levittää tomuaan." ${ }^{10}$ Tuo Ranskan kirjallisuuden ruumiin häpäisy oli ensimmäinen surrealistien masinoima poliittinen skandaali. Siitä lähtien 1900-luvun alun suuri poliittis-esteettinen avantgarde-liike oli jatkuvassa kiistassa esteettisen ja poliittisen vallankumouksen yhteyksistä ja eroista. Ennen kaikkea ongelmaksi muodostui, miten tämä elämän itsensä kumoamiseen pyrkivä avantgardistinen kumous yhdistyi yhteiskunnalliseen poliittiseen kumoukseen, ja oliko surrealistien maailma lainkaan yhdistettävissä marxilaisen materialismin kanssa, josta se haki liittolaista porvarillisen sovinnaisen humanismin ja realismin ylittämiseen kokonaisvaltaisessa elämän vallankumouksessaan. Surrealismi törmäsikin jatkuvasti ongelmaan siitä, kumpi vallankumous pitäisi asettaa ensisijaiseksi, ja 30-luvun vaihteessa Surrealistinen vallankumous -lehti muuttui Surrealismi vallankumouksen pal- veluksessa-lehdeksi. Mutta kun surrealismin "paaviksi" syytetty Breton alkoi varsinaisesti ekskommunikoida poliittis-moraalisesti epäkorrekteja surrealisteja, hänet itsensä julistettiin vainajaksi uudessa Ruumis (un cadavre) -pamfletissa. ${ }^{11}$ Karkotettuja surrealisteja ympärilleen kerännyt Georges Bataille, jota Breton oli syyttänyt taantumuksellisesta silvottujen ruumiiden liiallisesta pyhittämisestä, kirjoitti siihen omat vainajan muistosanansa: "Tässä lepää Breton-sonni, Kristuksen päätä kantava vanha esteetti ja väärä vallankumouksellinen." ${ }^{12}$ Bretonilaisen vallankumouksen yli-realismi sortui Bataillen mukaan samaan aurinkoa kohti kurottavaan ideaaliseen Ikaros-kompleksiin, joka oli sotkenut Nietzschen ihmisen kuolemaa julistanutta yli-ihmisen käsitettä, kun taas Marxin vallankumouksellisen myyrän ${ }^{13}$ pitäisi liikkua häpeällisemmässä alhaisessa materialismissa (bas materialisme) ${ }^{14}$ Myöhemmässä esteettis-poliittisessa päättömän miehen Acephalos-projektissaan Bataille asettikin sosialistisen ja kansallissosialistisen vallankumouksen ideaalisia representaatioita vastaan vielä puhtaamman kumouksellisen hajoamisen estetiikan. Leonardo De Vincin renessanssihumanismin klassisesti kuvittama Vitruviuksen harmoninen ihminen ilmaantuu nyt ex-surrealisti André Massonin piirtämänä päästä kastroituna ja suolistonsa paljastavana, sukuelimensä pääkallolla korvaavana primitiivinä. Bataille samaisti hahmon Nietzschen "yli-ihmiseen, joka ON kokonaisuudessaan 'Jumalan kuolema". ${ }^{15}$ Tuossa itsensä ulkopuolelle suuntautuvassa ekstaattisessa kumouksen hetkessä "yli-ihminen ja acéphale liittyvät yhteen hehkussa, joka vastaa ajan asemaa käskevänä kohteena ja elämän räjähtävää vapautta". ${ }^{16}$

Suuret surrealistiset kiistat ihmisen ylittämisen tai alittamisen poliittisista kamppailuista jäivät kuitenkin toisen maailmansodan marssivien sotilaiden jalkoihin, ja vanha ihmisen kumouksen viha-rakkaus-taistelupari, enkeli (Breton) ja hirviö (Bataille), vetäytyivät sekä Pariisista että poliittisista liikkeistä puhtaammin kirjallis-esteettisiin kokeiluihin. ${ }^{17}$ Uuden poliittis-kirjallisen 
intellektuellin ruumiillistumaksi noussut Sartre oli sitouttanut sotaa edeltäneen antihumanistisena pidetyn eksistentialismin nyt konkreettisen ihmisen vapauttamisen marxilais-humanistiseen projektiin ja näki Bretonin "Muuta maailmaa, muuta elämää" -iskulauseen paljastavan puhtaan "porvariintellektuellin", sillä "todellinen marxisti ei hetkeäkään epäile sitä, että vain yhteiskunnallinen muutos voi mahdollistaa tunteiden ja ajatusten radikaalin muutoksen" ${ }^{18}$ Sartrelle yhtäkään lukijaa työväestöstä tavoittamattomat surrealistit jäivät itsekriittisiksi ja parasiittisiksi porvaripojiksi, jotka "eivät pyri kaikkoamaan porvariluokasta, vaan pyrkivät pois ihmisen osastaan". ${ }^{19}$

Bretonin kuollessa vuonna 1966 Sartren ja Les Temps Modernes -lehden valtakausi kirjallisuuden suunnannäyttäjänä oli kuitenkin jo mennyttä ja uuden romaanin ympärille muodostuneet avantgardistiset kirjallisuuspiirit ja etenkin Tel Quel olivat löytäneet uudelleen sekä Bretonin että Bataillen arvon kielellisinä kielen rajojen kokeilijoina. Niinpä Arts et loisirs -lehti kutsui Sanoilla ja asioilla julkisuuteen noussutta ja modernin kirjallisuuden radikaalia kumouksellisuutta ihmisen kyseenalaistamisessa jälleen korostanutta "vuoden 1966 filosofia" ${ }^{\prime 2}$ tekemään eräänlaisen nekrologisen jälkikatsauksen Bretonin ja surrealismin merkityksestä. Itse vahvasti surrealistisista kirjailijoista ja kielellisistä kokeiluista vaikuttunut Foucault poikkesi kuitenkin vanhasta surrealistisesta ruumiin häpäisemisen perinteestä ja tarjosi Bretonin merkityksestä hyvin strukturalistisen nekrologian. Hän katsoi kokeneensa Bretonin mielikuvan jo kauan sitten kuolleen miehen paikkana, valtavana tyhjyytenä, jonka pohjalta moderni kokemus oli luonut merkityksiä. Näin "Bretonin kuolema oli kuin oman syntymämme kahdennus", ${ }^{21}$ sillä nykyajattelu löysi itsensä jälleen tuosta tyhästä tilasta. Foucault'n nekrologiasta teki erityisen tiedon arkeologin ehdotus korvata mielikuva Bretonista "mielettömyyden runoilijana" mielikuvalla tästä "tiedon kirjoittajana" (écrivain du savoir). Foucault nosti Bretonin jopa eräänlaiseksi Ranskan Goetheksi tehden surrealistisesta romaanista ranskalaisen bildung-romaanin, jossa ensi kertaa sitten Diderot'n oli kyse taas tietona käsitetystä kirjallisuudesta. Mutta jos saksalainen bildung-romaani pyrki tekemään kirjallisuudesta tietoa tietämyksen sisäistämisenä ja maailman halutunottamisena ihmisen mitassa, niin Bretonille sitä vastoin "tieto kirjallisuutena ja kirjallisuus tietona on tapa puskea ihminen rajojensa yli, pakottaa tämä kohtaamaan mahdoton ja saattaa lähelle sitä mikä tälle on kaukaisinta". ${ }^{22}$ Foucault korosti, kuinka surrealismille tiedostamattoman, hulluuden ja unien kysymys oli tiedon kysymys. Bretonin kuuluisa "rikkomaton yön ydin", ${ }^{23}$ jonka nuori Foucault oli nähnyt unen "absoluuttisena totuutena", ${ }^{24}$ oli itse asiassa päivän sydämessä, ei romantiikan lailla päivän herättämässä yön pimeydessä. Samalla ranskalaisen kirjallisuuden maanpakoon ajama ja Bretonin löytämä "kuvittelukyvyn kuningaskunta" ei ole jotakin, joka "syntyy ihmisen hämärässä ytimessä vaan jotakin mikä nousee diskurssin valoisasta tiheydestä". ${ }^{25}$ Foucault ylistikin Bretonin luomaa ihmiselle ulkoisen tiedon mielikuvituksen surreaalista vastamaailmaa vastakuvana tietoisen subjektin maailmaa konstituoivalle kuvittelukyvylle ja asetti samalla Bretonin täydellisenä vastakuvana sartrelaiselle poliittisesti sitoutuneelle kirjallisuuskäsitykselle. Kysymykseen Bretonin surrealismin poliittisuudesta Foucault vastasi sen olleen "vallankumous, ei poliittinen vaan absoluuttinen valta muuttaa elämää", ${ }^{26}$ ja katsoi Bretonin pyrkimyksen muodostaa kirjoitus maailman antimateriaalisuutena yhteensopimattomaksi sartrelaisen eksistentialismin tai marxismin kanssa, jossa kirjoitus tapahtuu aina maailman osana. Bretonin ansiona oli vapauttaa kirjallisuus kaiken sen sisällön tai kaikkien sen ilmaisemien ideoiden moralisoinnista ja samalla uudelleen moralisoida se puhtaana kirjoituksen tekoon liittyvänä kokemuksena, kirjallisena vapautena ja sanojen luomaan vastamaailmaan sisältyvänä kirjoituksen etiikkana. Kun kirjoitus pakotettiin kaiken 
sen ulkopuolelle mitä siinä voidaan sanoa, se sai itsessään uuden kiven kaltaisen jykevyyden, ja Breton, "uimari kahden sanan välillä", ${ }^{27}$ löysi tuosta kokemuksesta ennen kokemattoman mielikuvituksen tilan.

Mutta vaikka Sanoissa ja asioissa ja sen ympäriltä annetuissa haastatteluissa Foucault näytti olevan ennen kaikkea kiinnostunut tiedon muutosten aiheuttamista tietoisuuden vallankumouksista tieteiden ja taiteiden alueella, oli vuosi 1966 myös alkusoittoa uudelle esteettisen ja yhteiskunnan poliittisen vallankumouksen väliselle uintiretkelle. Taiteen ja politiikan ykseydestä, kuitenkin taiteellisen muodon ja poliittisesti oikeaoppisen sisällön erottavana "kahden rintaman taisteluna", ${ }^{28}$ puhunut 70 -vuotias puhemies Mao oli aloittanut nuorison avulla kulttuurivallankumouksen omaa puoluekoneistoaan vastaan ja vahvistanut nuorekasta uudistusvoimaansa uimalla Yangtze-joessa. Samana vuonna Strasbourgin situationisti-opiskelijat julkaisivat pamfletin "opiskelijaelämän surkeudesta", ${ }^{29}$ joka hyökkäsi koko taiteen muodon ja elämän sisällön erottelua vastaan modernissa spektaakkelin yhteiskunnassa nähden myös Maon kulttuurivallankumouksessa vain "modernien aikojen jättimäisimmän byrokratian esittämän valekumouksen". ${ }^{30}$ Julistaen Bretonin sanoin "maailman ja elämän muuttamisen olevan sama asia proletariaatille" se vaatii rajoituksetonta nautintoa ja ilmoitti, että "vapaa luovuus kaikkien elämän tapahtuminen ja hetkien rakentamisessa oli ainoa sen tunnustama runous". ${ }^{31}$ Situationistit hyökkäsivät myös ex-surrealisti Louis Aragonin elokuvallisen vasemmistoavantgarden kärkinimeksi nostamaa Jean Luc Godardia vastaan, joka vuorostaan maolaisia opiskelijoita lähestyttyään teki kaikki mahdolliset tahot suututtaneen poptaidetta sekä maolaista fraseologiaa ja estetiikkaa sekoittavan avangardistis-brechtläisen opetusnäytelmäelokuvan Kiinatar (1967). Siinä maolaisen "Aden Arabie solun" Guillaume Meister ${ }^{32}$ ampuu jousipyssyllä kohti marxilais-leniniläisen vallankumouksen maalia, jota ympäröivistä vallankumouksen vihollisista silmään pistää Foucault'n Sanat ja asiat -teos. ${ }^{33}$ Solun luennoissa kritisoidaan ihmisen lopusta puhuvia ihmistieteitä ja Nanterren yliopistolla opiskeleva Yvonne (Anne Wiazemsky) haluaisi räjäyttää yliopistot, jossa kehdataan ylistää revisionistisesti sanat ja asiat sekoittavaa kirjaa. Taistelu kahdella rintamalla -keskustelussa Godard ilmoittikin tekevänsä elokuvia, jotteivät kunnioitetut tohtori Foucault't saattaisi kertoa meidän ajattelevan aina välttämättä tietyllä tavalla. ${ }^{34}$ Vain vuotta myöhemmin juuri Nanterren yliopistolta alkaneessa opiskelijavallankumouksessa situationistien graffitit julistivat vuorostaan: "Taide on kuollut. Eikä Godard voi sille mitään." 35

\section{VETELÄSTÄ HUMANISMISTA}

\section{RAKENTEIDEN POLITIIKKAAN}

Ihminen etsi yli-ihmistä (übermenschen) fantastisesta taivaiden todellisuudesta ja löysi vain oman kuvajaisensa. Siellä missä hän nyt etsii ja missä hänen täytyy etsiä itsensä todellisuutta (wirklicheit), ei hän enää tyydy vain itsensä kajoon (Schein), epäihmiseen (unmenschen). (Karl, Marx: Hegelin oikeusfilosofian kritiikkiä.)

Foucault'n varhaisemmat teokset hulluuden tai sairauden kokemuksista eivät herättäneet suuria poliittisia tunteita, vaikka niissä psykiatrisen ja lääketieteellisen tiedon muutokset oli liitetty vahvasti Foucault'n tuolloin vielä varsinaisesti eksplikoimatta jättämään yhteiskunnallisten valtakäytäntöjen kenttään. Sen sijaan lähes puhtaasti tiedon rakenteellisiin muutoksiin keskittyvä SA aiheutti kenties Foucault'n kaikista teoksista suurimman poliittisen myrskyn. Ranskan kommunistinen puolue (PCF) tuomitsi sen oikeistolaisena ideologiana ja Neuvostoliiton johtava kirjallisuuslehti Literaturnaja Gazeta kirjoitti Foucault'n vastustavan marxismia, koska se oli aikansa todellista humanismia.

Ihmisen eskatologian (lopun) ihmisen apokalypsin (ilmestys) tilalle asettanut SA ilmestyikin 1960-luvun puolivälissä keskelle strukturalististen ihmistieteiden aktualisoimaa marxismin humanistikiistaa. Jo 
20-vuotta aikaisemmin eksistentialismi oli aktualisoinut vastaavan kiistan Sartren humanismin suhteesta L'Humanité -päivälehteä julkaisevan ja neuvostomarxismin uuden ihmisen rakennustyötä virallisesti kannattaneen PCF:n marxismin välillä. PCF oli selvinnyt toisen maailmansodan Ranskalle hämillisestä "voitosta" varsin puhtain paperein ja mainosti itseään 75000 teloitetun puolueena. Vastarintaliikkeen ruumiiden sädekehät saivatkin sen hohtamaan muita poliittisia ryhmittymiä kirkkaammin etenkin nuoren älymystön keskuudessa, jolle Foucault'n nuoruuden kuvauksen sanoin sodan kokemus kertoi välttämättömyydestä luoda radikaalisesti erilainen yhteiskunta kuin se, joka oli huorannut natsien kanssa. ${ }^{36}$ Sartren eksistentialismi puhutteli kuitenkin nuorten kokemusta virallista marxismileninismiä vahvemmin, ja kun vastarinnan edustajaksi asettunut Sartre alkoi vielä yhdistää sitä yhteiskunnalliseen humanistiseen kumoukseen, hän sai PCF:n intellektuellit hyökkäämään eksistentialistista antihumanismia vastaan aidon marxilaisen humanismin nimissä. Sartren sättimisen vei pisimmälle tämän entinen oppilas ja myöhemmin PCF:n teorialehden (La Nouvelle Critique) päätoimittaja Jean Kanapa, joka julisti koko Les Temps modernes -lehden väen fanaattisiksi trotskilaisiksi L'Existentialisme n'est pas un humanisme -manifestissaan. ${ }^{37}$ Lähtien liikkeelle nuorten yhteiskunnallisesta situaatiosta Sartre taas syytti "Materialimi ja vallankumous" -artikkelissaan PCF:n edustamaa dialektista materialismia metafysiikaksi ja asetti sitä vastaan ihmisen konkreettisen situaation vapauden tunnustavan eksistentialismin vallankumouksellisempana oppina. ${ }^{38}$ Kiihkeässä polemiikissa Henri Lefebvre jopa yltyi psykologisoimaan eksistentialismin narsistiseksi patologiaksi, porvarillisen nuoruuden skitsofreniaksi, jota oli itse sairastanut 20-luvulla. Dadasta ja surrealismista innostuneena hän oli siirtynyt vasemmistolaiseen poliittiseen toimintaan ja löytänyt parannuksen feminiiniseen eksistentialismiin miehisen kypsästä työläismarxismista. ${ }^{39}$ Lefebvren myöhemmin ka- tuma maskuliininen purkaus oli myös siinä suhteessa yllättävä, että hän itse vastusti kaikkea luonnondialektiikkaa lähestyvää marxilaisuuden tulkintaa ja oli vastuussa juuri nuoren "eksistentialistisen" Marxin kirjoitusten johdattamisesta ranskalaiseen keskusteluun. Lefebvre oli julkaissut teoksen dialektisesta marxismista juuri samana vuonna, kun Stalin esitti siitä oman luonnontieteelliseen objektiivisuuteen pyrkivän virallisen Диама́m-mallinsa "marxilais-leniniläisten puolueiden virallisena oppina". ${ }^{40}$ Lefebvrelle kyse ei ollut Stalinin luonnondialektiikkaa lähestyvästä tieteestä vaan kohti totaalisen ihmisen vapautta historiassa liikkuvasta "elävän subjekti-objektin" ${ }^{41}$ käytännöllisestä filosofiasta. "Totaalinen ihminen on ei-vieraantunut ihminen." ${ }^{42}$

Juuri Pariisissa sata vuotta aikaisemmin nuori Marx oli kirjoittanut käsikirjoituksen yhteiskunnallisesta vieraantumisesta Hegelin fenomenologian ja Feuerbachin humanistisen kritiikin pohjalta ja esittänyt, että siinä missä "ateismi Jumalan kumoamisena on teoreettisen humanismin koitto, kommunismi yksityisomaisuuden kumoamisena ja todellisen inhimillisen elämän osoittamisena tämän omaisuutena on käytännöllisen humanismin koitto" ${ }^{43}$ Kommunismi oli saksalaisen filosofian uskontokritiikin konkretisoivaa ja filosofian itsensä täydellistävää todellista humanismia, ratkaisu "ihmisten ja luonnon sekä ihmisten välisiin ristiriitoihin, todellinen ratkaisu riitaan olemisen ja olemuksen, esineellistämisen ja itsevahvistuksen, vapauden ja välttämättömyyden, yksilön ja lajin välillä”. ${ }^{4}$ Tämä nuoren Marxin lupaus vieraantumisen voittaneesta ihmisestä voitiin asettaa vastakkain Stalinin uuden neuvostoihmisen propagandan kanssa ja liittää terästeollisuuden tuotantolukujen mittaamisen sijaan länsimaisen hengen kohtalon filosofiseen pohdintaan. Samalla se yhdisti Marxin itsensä vankemmin Hegelin Hengen fenomenologian historialliseen antropologiaan, joka tarjosi ranskalaisessa filosofiassa uuden vaihtoehdon kartesiolaiselle traditiolle ja mahdollisti samalla marxismin ymmärtämisen positivistisen 
materialismin sijaan vieraantumisen negatiivisuuden ylittävänä positiivisena humanismina. Niinpä Foucault'n Hegel-opettajan Jean Hyppoliten mukaan "Marxin talouspoliittiset käsikirjoitukset eivät ole muuta kuin Hengen fenomenologian kommentaaria" ${ }^{45}$ ja nämä vieraantumisesta keskeisen kysymyksen tehneet kirjoitukset "kenties sisältävät tämän koko filosofian merkityksen ja perustan, paljastaen klassisen taloustieteen ja Hegelin filosofin kaksoisvaikutuksen". ${ }^{46}$ Hyppoliten mukaan käsikirjoitusten vaikutus olikin valtava kokonaiselle sukupolvelle, joka asetti nyt vieraantumisen ongelman filosofis-yhteiskunnallisen kysymyksen keskiöön.

Yhteiskunnallinen vieraantuminen oli teema, jonka kautta myös nuori Foucault oli pyrkinyt liittämään marxilaista analyysia psykologis-filosofiseen kysymykseensä mielisairauteen liittyvästä vieraantumisen kokemuksesta. Opiskelijana Foucault oli toisenlaisen olemassaolon mahdollisuutta etsiessään liittynyt kommunistiseen puolueeseen ja muodostanut hetken aikaa ortodoksien "Saint-Germain-des-Prés-marxisteiksi" haukkuman ryhmän yhdessä myös sittemmin ihmistieteiden rintamalla kunnostautuneiden Paul Veynen, Jean-Claude Passeronin ja Gérard Genetten kanssa. ${ }^{47}$

Olimme tutkimassa toisia teitä ohjamaan meitä kohti sitä täysin toista, jonka uskoimme ruumiillistuvan kommunismissa. Siksi liityin puolueeseen tuntematta Marxia kovin hyvin, kieltäytyen hegelismistä ja tuntien eksistentialistisen vapautuksen heikoksi. "Nietzscheläinen kommunisti", se todellakin oli eletyn mahdollisuuden rajoilla ja sitä voidaan sanoa naurettavaksi. Tiedän sen hyvin. ${ }^{48}$

Foucault itse sanoi lähteneensä puolueesta tiedonpoliittisista ja moraalisista syistä. Hän ei enää sietänyt poliittisen sitoutumisen vaatimaa tiedon vastaista vakaumusta tai sen porvarillistakin porvarillisempaa sukupuolimoralismia. Silti myös esteettisellä politiikalla saattoi olla asiaan vaikutusta. Vuonna 1953 nimittäin kuoli punainen Jumala, ja vaikka Moskova oli jo tuominnut Picasson rappio- taiteena, Louis Aragon, yksi surrealismin alkuperäisistä "kolmesta muskettisoturista", ${ }^{49}$ uskalsi kuitenkin pyytää puoluetoveri Picassolta muotokuvaa kuolleesta Stalinista Les Lettres françaises -lehden kanteen. Lukijat raivostuivat tuosta "puhtaimpia tunteita" loukkaavasta kuvasta, jossa suuri toveri ei näyttänyt uuden ihmisen aurinkoiselta isältä vaan viiksekkäältä naiselta. Surrealistit olivat taas häpäisseet suuren vainajan ruumiin, ja Aragon pyysi anteeksi lukijoiltaan ja puolueelta epäkypsää ja oppimatonta virhettään. Samana vuonna Samuel Beckettin Huomenna hän tulee -näytelmän ensiillassa täysin haltioitunut nuori Foucault jätti puolueen lopullisesti.

Kun Sartre sitten syytti SA:ta porvariston suojamuuriksi, Foucault katsoi tämän vain toistavan hänen ja puoluetoveriensa nuorina esittämää kritiikkiä Sartrea vastaan. Sartre olikin pitkään PCF:n hyökkäyksen kohteena ja vasta 50-luvun puolivälissä lähestyi puolueen edustamaa marxismi-leninismiä, samaan aikaan kun hänet marxismiin tutustuttanut Maurice Merleau-Ponty taas lakkasi luottamasta poliittisen tietoisuuden ohjaamaan proletariaattiin modernin politiikan ensisijaisena empiiris-transsendentaalisena subjektina. Merleau-Pontyn humanistisessa marxismissa kommunismi oli ollut yritys "ratkaista ihmisen ongelma" 51 ja marxismi lausuma "niistä ehdoista, joita ilman ei olisi humanismia ihmisten välisenä suhteena tai minkäänlaista rationaalisuutta historiassa".52 Nuoren Marxin sanoin proletariaatti oli tuo säädytön sääty, luokaton kaikkien luokkien kumoaja, joka saattoi provosoida vain universaalin vääryyden ja ihmisyyden nimissä. Vieraantumisen voittava teorian ja käytännön humanistinen yhteys, filosofian täydellistäminen ja kumous (aufhebung) oli vastavuoroinen proletariaatin kumouksen (aufhebung) kanssa. ${ }^{53}$ Merleau-Pontylle marxismi ei ollutkaan historianfilosofia muiden joukossa vaan itsessään inhimillisesti merkityksellisen historian empiiris-transsendentaalinen ehto, jos "historia tarkoittaa ihmisyyden syntymistä ja ihmisyys ihmisten välistä toistensa tunnustamista ihmisinä". ${ }^{4}$ 
Weberiä lukeneelle fenomenologille merkityksellinen historia ei ollut kuitenkaan objektiivisten lakien hallitsema vaan väkivaltaiseen maailmakokemukseen heitetyn intersubjektiivisen merkityksen toteuttamista. Humanismin ja väkivallan suhteen pöydälle nostavissa ja skandaalimaisina pidetyissä Humanismi ja terrori-esseissään Merleau-Ponty korostikin humanismin lupauksen olevan ainoa kommunistisen väkivallan väkivaltaisessa maailmassa oikeuttava lupaus. Stalinin terrorin edessä kysymys ei ollut siten väkivallan hyväksymisestä tai proletariaatin hylkäämisestä vaan kysymyksestä: "Vastaako kommunismi edelleen sen humanistisia intentioita." ${ }^{55}$

Mutta jos Stalin merkitsi Merleau-Pontylle trotskilaisesti "petettyä vallankumousta", niin tuon kojèvelaisen historiallisen antropologian theanthropoksen kuolema ja Hruštšovin vuonna 1956 pitämän "lähes jumalaksi nostetun yli-ihmisen (сверхчеловека)" ${ }^{156}$ kuvainpalvontaa kritisoivan salaisen puheen leviäminen nostivat uuden destalinisaation aallon, joka näytti mahdollistavan taas sosialistisen humanismin lunastamisen. "Destalinisoijat ovat edelleen stalinisteja", ${ }^{57}$ kirjoitti kuitenkin Merleau-Ponty vuonna 1956 ja näki nyt Stalinin kultin kovasanaisen tuomitseminen vain vahvistavan tämän miljoonien ihmisten yläpuolelle nousevaa yli-ihmisyyttä ja estävän kommunismin rakenteellisen itsekritiikin. Eilisen kaikkivaltiaan yksilöpsykologiasta tuli tämän päivän kaikki paheet pois vievä syntipukki. Merleau-Ponty kritisoi nyt myös Sartrea ultrabolševistisesta subjektin voluntarismista tämän pyrkimyksessä perustaa luokkatietoisuus historiallisen proletariaatin sijaan historian puhtaalle negaatiolle. ${ }^{58}$ Korean sodan aikana ja etenkin Unkarin kansannousun vuoksi Merleau-Ponty oli alkanut menettää uskoaan proletariaatin humanismin historiallis-konkreettisen toteutumisen lupaukseen. Historialliset tapahtumat ilmaisivat syvää eurooppalaisen kommunismin kriisiä, jota ei vonut fenomenologisesti elvyttää palaamalla kommunismin alkuperäiseen merkityshorisonttiin ja vallankumoukselliseen aktiin. Historial- lisen proletariaatin maailman muuttamisen lupauksen kuolema merkitsi samalla koko teorian ja käytännön yhdistämisen kriisiä. Marxilaisella filosofialla ei ollut enää humanismin lupauksen antamaa historiallisen merkityksen monopolia, ja sen oli suhteellistettava itsensä historian ja filosofian ongelmallisemmassa suhteessa. Aika kutsui filosofiaa taas ennemmin tulkitsemaan kun muuttamaan maailmaa. Kirjaimellisen totuuden sijaan Marxin itsensä oli muututtava Descartesin tapaisten filosofian klassikoiden edustamaksi "toissijaiseksi totuudeksi" ${ }^{59} \mathrm{Fi}-$ losofian jumalainen ihmisen apokalypsi oli ohi, ja sen uusi tehtävä oli paljastaa vaatimattomammin näkyvän ja näkymättömän kiasma konkreettisessa olemisessa. "Ihminen on salattu, hyvin salattu ja tällä kertaa meidän ei pidä erehtyä siitä." ${ }^{\prime 60}$

Merleau-Pontyn humanistisen pessimismin sijaan Stalin kuolema loi kuitenkin uuden ihmiskasvoisen sosialismin optimismin ja myös suhteellisen hitaasti destalinisoitunut PCF kääntyi lopulta kohti jälkistalinistista humanismin oppia. "Sosialistinen humanismi on päivän sana" ${ }^{61}$ totesikin Louis Althusser vuonna 1964 julkaistussa poleemisessa "Marxismi ja humanismi" -esseessään, joka oli kirjoitettu Erich Frommin pyynnöstä sosialistista humanismia käsittelevään yleiseurooppalaiseen kirjoituskokoelmaan. ${ }^{62}$ Teksti ei kuitenkaan sopinut teokseen sen humanismia kohtaan ottaman kriittis-ironisen asenteen vuoksi. Althusser kirjoitti, kuinka Neuvostoliiton nähtiin nyt siirtyneen luokkahumanismia edustavasta Stalinin proletariaatin diktatuurista luokattomaan persoonalliseen sosialistiseen humanismiin. Näin se toteutti lopulta sekä kristillisen ja porvarillisen humanismin kesken jääneet unelmat että Marxin nuoruuden profetiat: "Ihmisen valtakausi oli vihdoin alkamassa." ${ }^{63}$

Althusserin idea ei ollut palauttaa sosialistiselle humanismille Stalinin kasvoja vaan vapauttaa marxilainen yhteiskuntateoria humanismin apokalyptiikasta. Ranskalaisesta tieteenhistoriallisesta koulukunnasta vaikuttuneelle Althusserille humanismi oli ideologinen käsite, ja hän esitti Bachelardin 
tapaan, että tieteellinen teoria oli puhdistettava ideologisista jäänteistään. Althusser lukikin Marxia ranskalaisen epistemologisen perinteen kautta korostaen teoreettista käytäntöä ja tieteen ideologiasta erottavaa epistemologista katkosta. Jos Marx oli erityisen historiallisen (ei siis fysikaalisen) yhteiskuntatieteen perustaja, kuten Althusser väitti, oli kysyttävä, missä tuo tiede ylitti epistemologisen kynnyksensä ja saattoi erota ideologiasta. Althusserin mukaan tämä tapahtui Marxin itsensä ajattelussa, jonka varsinainen tieteellinen löydös oli tämän nuoruutensa humanismiin tekemä käsitteellinen katkos (rupture). Tuo katkos teki Marxin ajattelussa lopullisen eron sekä varhaiseen Kantilta perittyyn rationalistisliberaaliin ihmisluonnon humanismiin että Feuerbachilta perittyyn vieraantumishumanismiin. ${ }^{64} P \ddot{a} a-$ oman edustaman tieteellisen marxismin kehittäminen saattoi siis perustua vain teoreettiselle antihumanismille. Althusserin essee ja tämän seuraavana vuonna oppilaidensa kanssa julkaisemat Cavaillèsin, Bachelardin, Canguilhemin ja Foucault'n töistä inspiroituneet epistemologiset luennat Pääomasta nostivatkin rue d'Ulmin kaimaanin hetkessä École normale supérieuren eliittikoulun kammioista kansainvälisesti tunnetuksi marxilaisen teorian edelläkävijäksi. ${ }^{65}$ Mutta samalla ne aloittivat kommunistisen puolueen sisällä suuren humanistikiistan, kun puolueen viralliseksi filosofiksi noussut Roger Garaudy aloitti hyökkäyksen Althusseria ja tämän oppilaita vastaan: "On esitetty perustava ongelma: marxilaista humanismia vastaan on hyökätty tieteen nimissä." ${ }^{66} \mathrm{Ai}$ koinaan Sartren eksistentialismia vastaan stalinismin nimissä hyökännyt Garaudy olikin nyt siirtynyt uuteen moraaliseen humanismiin ja pyrki lähestymään katolisia humanisteja houkutellen näitä kommunistien kanssa humanistiseen yhteisrintamaan. Kuukautta ennen SA:n ilmestymistä PCF:n keskuskomitea julisti Althusser-Garaudy kamppailun tuloksen: "Marxismi on aikamme humanismia." 67

Ihmisen häviämistä uuden ajattelun mahdollisuutena julistanut SA liitettiin tie- tenkin heti tähän humanistikiistaan. Garaudy kirjoitti SA:n olevan "positivistinen" oikeistolainen teos, joka ei huomioinut objektivisuuden historiallista todellisuutta ja sen muutoksen subjektiviteetin periaatetta: "Puoluetta, tietoisuutta ja toimintaa." 68 Garaudy, jonka moralistista marxismia Foucault ei voinut sietää, oli tämän vanha kollega Clermont-Ferrandin yliopistosta ja haastatteluissa Foucault ylistikin entisen kaimaaninsa Althusserin kamppailua puolueessa "chardino-marxismia"69 vastaan. Mutta SA hermostutti myös erityisesti Hulluuden historiasta innostuneen Althusserin ja tämän oppilaat väittämällä, ettei Marxin tuotantosuhteiden analyysi merkinnyt uuden tieteen synnyttävää epistemologista katkosta. $^{70}$ Foucault tosin yritti lieventää lausumaansa sanomalla, että Marx toki synnytti radikaalin katkoksen ihmisten poliittisessa tietoisuudessa. Hän sanoi kritisoineensa vieraantumisen lopettamisen antropologista unta ja jopa suunnittelevansa SA:n jatko-osaksi tutkimusta länsimaisen tiedon ja historiatietoisuuden suhteista renessanssista lähtien. Tässä tutkimuksessa Marxilla olisi merkittävämpi rooli. ${ }^{71}$ Vastauksena nuorten marxilaisten epistemologisen ryhmän kritiikkiin syntyneessä Tiedon arkeologiassa Foucault antoikin Marxille positiivisemman roolin subjektin varaan rakennetun jatkumollisen historian purkajana ja juuri materiaalisten ei-subjektiivisten yhteiskunnallisten suhteiden analyysin aloittajana. ${ }^{72}$ Puolueesta erottuaan Foucault ei kuitenkaan itse koskaan enää ollut marxilainen, eikä Marxin yhteiskuntateoria edustanut hänelle sen enempää tiedettä kuin pelkkää ideologiaa vaan oli Marxin alustama yhteiskuntaa tietyllä tavalla analysoiva historiallis-diskursiivinen käytäntö. Ideologian ja tieteen eroa korostava Althusser taas totesi kaiken politiikan ja käytännön, myös hänen itsensä kannattaman kommunistisen politiikan, olevan aina välttämättä ideologiasta. Niinpä vaikka Althusser kielsi humanismin teoreettisen arvon, hän oli valmis antamaan marxilaiselle humanismille saman käytännöllisen ideologisen postulaatin arvon, jonka Kant 
oli antanut Jumalalle kiellettyään kaikkivaltiaan tietoteoreettisen merkityksen. "Humanismin käskysanalla ei ole teoreettista vaan käytännöllisen indeksin arvoa."73

Aikakauden haastatteluissa Foucault taas esiintyi Althusseria ankarampana antihumanistina, joka halusi eroon humanismista myös poliittis-ideologisena käytännön postulaattina. "Tehtävämme on vapautua täydellisesti humanismista [...] työni on poliittinen työ siinä määrin kuin kaikki hallitukset sekä idässä että lännessä asettavat kauppatavaransa humanismin paviljonkiin.." ${ }^{14}$ Foucault analysoi, kuinka jumalan käsitteen menetettyä tiedollisen arvonsa sitä yritettiin edelleen perustella kaiken moraalin välttämättömänä mahdollisuusehtona. Nyt ihmisen käsitteen menetettyä tiedollisen arvonsa se katsottiin kuitenkin välttämättömäksi mahdollisuusehdoksi kaikelle moraalille ja politiikalle. Moraalisen humanismin puolustuksen edessä Foucault hämmästyttikin haastattelijoitaan puhumalla humanismin rikoksista. Siinä missä Luther oli kuuluisasti kutsunut järkeä "saatanan suurimmaksi huoraksi", ${ }^{75}$ Foucault sanoi humanismin olleen jo yli 20-vuoden ajan stalinismissa, kristillis-demokratiassa ja eksistentialismissa kaiken ajattelun, kulttuurin, politiikan ja moraalin "pikkuhuora". ${ }^{76}$ SA:n julistama ihmisen loppu ei merkinnyt ihmistieteiden loppua vaan näiden vapautumista analysoimaan rakenteita ja järjestelmiä. Samoin järjestelmien ja rakenteiden muuttamiseen tähtäävä tiedon politiikka ei hänen mukaansa tarvinnut sen enempää "vetelää humanismia"77 kuin "tietämättömyyden opin politiikkaa, jota kutsutaan sitoutumiseksi". ${ }^{78}$

Vaikka Foucault on usein nähty valistuksen pimeän puolen teoreetikkona, joka analysoi järjen ihmistä objektivoivia ja kurinalaistavia tekniikoita, hän itse asiassa asetti aina valistuksen tiedon ja kriittisen järjen projektin humanististen ideologioiden edelle, nähden jälkimmäisen aina palvelevan "tiettyjen ihmiskäsitysten värittämistä ja oikeutusta, jotka se on velvoitettu täyttämään”. ${ }^{79}$ Foucault huomauttikin nykyfeminismin kyseenalaistamien niin sa- nottujen naisellisten hyveiden kuuluneen aikoinaan kaikkien mielestä itsestään selvinä universaaliin humanismiin. Hän vaati mahdollisuutta käsitellä poliittisesti yhteiskunnan toimintaa ja yksilöiden vapauksia ja tarpeita sortumatta mihinkään oletetun ihmisyyden toteuttamisen ideologiaan. Ruotsissa annetussa haastattelussa Foucault yllättäen ylisti skandinaavista todellisuuden kauniin ja ankaran välttämättömyyden säännöstön hiljaisuutta antihumanistisena politiikkana, jossa järjestelmän toimivuus on ihmisonnen hämärästä päämäärästä vauhkoilua keskeisempi ongelma. ${ }^{80}$ Kun Foucault'ta syytettiin tämän vuoksi teknokratiasta, hän vastasi juuri "teknokraattien olevan suurimpia humanisteja", ${ }^{81}$ sillä teknokratia on sidottu asetetun tai oletetun ihmisen päämäärän tehokkaaseen toteuttamiseen. Ennen SA:n ilmestymistä Foucault oli kuitenkin osallistunut poliittisesti lähinnä vain gaullistisen hallinnon teknokraattisiin yliopistouudistuksiin, ja hänen uusi radikaalimpi poliittinen aktiivisuutensa alkoi vasta poliittisten kysymysten ja rakenteiden kentän muututtua 1960-luvun lopun opiskelijaliikehdinnän seurauksena.

Strukturalismin huippuvuotta 1966 seurasikin pian uusi politiikan hullu vuosi. ”22.5.1968 Pariisissa ei ollut säätä. Kaikki säämiehet olivat lakossa." ${ }^{2}$ Vanhoja surrealistisia iskulauseita kierrättänyt yliopistonuorten aloittama "muuta elämää" -protesti oli levinnyt kokonaisvaltaiseksi yhteiskunnalliseksi kumoukseksi. Foucault itse vietti vuoden Tunisiassa ja oli kohdannut siellä niin rajuja ja väkivaltaisia opiskelijamellakoita, että niiden rinnalla Pariisin kevät 1968 näytti turvalliselta hauskanpidolta barrikadeilla ja hypermarxististen teorioiden loputtomilta kielipeleiltä. Foucault alkoi kuitenkin kiinnostua nyt kielen ongelman sijasta yhä enemmän vallan ja väkivallan ongelmasta. Myöhemmin hän antoikin vallan taisteluille SA:ssa vielä kielelle antamansa historiallista merkitystä konstituoivan roolin. Foucault'n palattua Ranskaan Vincennesin kokeiluyliopiston filosofian laitoksen johtoon radikaaleimmat opiskeli- 
jat syyttivät häntä vuoden 1968 vastarinnan kunniamerkkien puutteesta ja kuulumisesta vastavallankumouksellisen strukturalismin leiriin. Opiskelijaliikehdintä olikin julistanut aluksi strukturalismin loppua ja vaatinut abstraktin akateemisina pidettyjen strukturalististen analyysien sijaan toiminnan käytännön kumousta. Strukturalismia kritisoineen Henri Lefebvren opiskelijat Nanterressa olivat keskeisiä kumouksen aloittajia, ja Sartre ilmaantui nopeasti julkisuuteen opiskelijoiden rinnalle. Althusser pysyi hiljaisena ja Lévi-Strauss kirosi kumouksen aiheuttamaa haittaa tieteelle. "Struktuurit eivät lähde kadulle" oli ollut yksi ajan iskulauseista, johon sittemmin György Lukácsin työn jatkajana Ranskassa esiintynyt Lucien Goldman taas vetosi Ranskan filosofisen seuran keskustelussa Foucault'n "Mitä on tekijä" -luennosta. Lacan tosin huomautti tähän osuvasti: "Jos toukokuun 1968 tapahtumat todella osoittivat jotakin, niin juuri rakenteiden lähtemisen kadulle." ${ }^{83}$

Toukokuu 1968 ei tosiaan tuonut muassaan vallan subjektin toisella korvaavaa vallankumousta sen enempää kuin se onnistui luomaan uuden ihmisen humanistista aamunkoittoa. Mutta sen radikalisoima "muuta elämää" -kumous oli osa laajempaa liikehdintää, jonka tyytymättömyys elämää hallitsevia rakenteita kohtaan kyseenalaisti vanhat poliittiset rakenteet, kumosi poliittiseksi nähtyjen asioiden rajat ja muodosti uudenlaisia poliittisia subjektiviteetteja. ${ }^{84}$ Kun Foucault'ta myöhemmin syytettiin toukokuun 1968 vähättelemisestä, hän myönsi sen olleen päinvastoin erittäin tärkeä tapahtuma, jota ennen hänen tutkimuksensa vankilasta tai seksuaalisuudesta olisivat olleet mahdottomia. Kaiken hypermarxistisen teoretisoinnin alla se oli ilmaus laajemmasta rakenteellisesta kokemuksen siirtymästä ja vastarinnasta erilaisille elämän hallinnan muodoille. Foucault liittikin sen vanhan dogmaattisen marxismin kuolemaan ja uuden vasemmiston syntyyn. "Ei-marxilainen vasemmistokulttuuri oli ilmaantumassa." 85 Samalla Foucault, joka ei ollut sitoutunut tai kiinnittynyt politiikkaan, löysi nyt oman ajattelunsa politiikan sidoksista, ja hänestä itsestään tehtiin vähitellen tuon uuden vasemmistokulttuurin keskeinen teoreetikko. Tieteenhistoriassaan Foucault'ta oli ollut kiinnostunut siitä, miten jokin aikaisemmin ei-tietona pidetty saattoi sittemmin tulla tiedon tai totuuden piirin ja taas pudota sieltä pois. Nyt häntä kiinnostaneet psykiatrian, sairauden, seksuaalisuuden, laitostamisen, medikalisaation ja niin edelleen ongelmat olivat yhtäkkiä tulleet poliittiseksi kysymykseksi. Foucault totesikin "tietyllä ylpeydellä, että tässä tapauksessa politiikka on lähestynyt minua tai se on vallannut yhä enemmän aloja, jotka olivat kvasipoliittisia, mutta joita ei tunnistettu sellaisina". ${ }^{86}$ Tämä poliittisen alueen muutos johti taas Foucault'ta itsensä kysymään noiden kokemuksien merkitystä vallan kokemuksina. "Kaikista noista kokemuksista, omani mukaan lukien, ilmaantui aivan kuin paperille näkymättömällä musteella kirjoitettu yksi sana, joka tarvitsi vain oikean kemiallisen yhdisteen ilmaantumiseensa näkyville, valta." ${ }^{87}$ Tämän vallan kritiikki ei voinut kuitenkaan perustua vain pyrkimykseen kumota ylivallan subjekti toisella "humanistisemmalla" subjektilla, vaan sen oli kyseenalaistettava vallan subjektit konstituoivat rakenteet sekä niissä toimivat vallan strategiat ja taktiikat. Miettiessään myöhemmin, miksi rakenteiden analyysiin pyrkivä strukturalismi herätti 60-luvulla niin voimakkaita poliittisia vastareaktioita, Foucault väitti sen muistuttaneen Stalinin historiallisen käytännön tuhoamasta itäeurooppalaisesta ja vasemmistolaisesta vallankumouksellisesta formalistisesta perinteestä. Foucault näki ihmiskasvoisen sosialismin Stalinin varjona, jolla yritettiin peittää uusien rakenteellisten kysymysten esiin nostaminen ja sosialistisen humanismin arkipäivän vankileirien ja laitosten väestöpolitiikka. Foucault'n vieraillessa juuri SA:n ilmestymisen alla vuonna 1966 Unkarissa hänen luentonsa siirrettiinkin pois opiskelijoiden auditoriosta heti hänen alkaessaan käsittellä tiedonpoliittisesti vaarallista strukturalismia. 
Museoiden MiElikuvitus

Sanoista ja asioista, pahan lailla pinotuista, väärin tavoin liitetyistä,

ajattelun anarkia, mielen melske, unet sekavat ja vaihtelevat nousta voi

nämä naisen silmiin tuon (Paholainen, John Dryer: Viattomuuden tila ja syntiinlankeemus.)

Pelastuksen olemus on kenties siinä, ettei se ilmoita itsestään merkeillä vaan keinottelee simulacrumien syvyydessä.' (Michel Foucault: Aktaion proosa.)

Vuonna 1966 Foucault'n Unkarin vierailun viralliseen matkaohjelmaan kuului myös vierailu humanistisen marxismin kulttuurija kirjallisuuskritiikin "isän" György Lukácsin luona. Tuo Taikavuoren "Nathan" oli nuorena etsinyt avantgardistien tapaan kiihkeästi elämän muutosta poispääsynä ensimmäisen maailmansodan korruptoituneesta maailmasta ja tarkastellut modernia romaania esityksenä ihmisen transsendentaalisen kodittomuuden kokemuksesta: "Romaani on Jumalan hylkäämän maailman eepos." 88 Löydettyään marxismista konkreettisen lupauksen ihmisen kodittomuuden maallisesta lunastamisesta Lukács oli vuorostaan Historia ja luokkatietoisuus -teoksessaan vallankumouksellistanut marxilaisen tietoisuuden kulttuurikriittisenä tietoisuutena ihmisen esineellistymisestä (Verdinglichung). ${ }^{89}$ "Kypsässä" realistisessa humanismissaan hän kuitenkin tuomitsi nuoruutensa messiaanisen marxismin ja varsinkin sitä edeltäneen romanttisen antikapitalismin. Kummatkin saivat nyt ilmauksen natsismiin johtavassa ja Nietzschestä inspiroituneessa ekspressionistisessa estetiikassa, jonka Lukàcs ehti tuomita rappiotaiteeksi jo ennen kuin natsit alkoivat esitellä sitä - rappiotaiteen näyttelyissään. ${ }^{90}$ Ekspressionistisen ilmaisun sijaan klassinen porvarillinen realismi edusti Lukàcsille ihmisen maailman esittämisen humanistisinta muotoa, joka vuorostaan täydellistyi proletariaatin humanistista taistelua kuvaavassa sosialistisessa realismissa. "Ensimmäisen sosialistisen realismin klassisen kirjoittajan"91 ruumiin äärellä, Ma- xim Gorgyn hautajaisissa Punaisella torilla, Lukàcs lausuikin vainajan muistuttavan, kuinka "marxismissa, bolsevismissa, humanistinen periaate on enemmän kuin ideaali, enemmän kuin etäinen mahdollisuus". ${ }^{92}$ Lukács toki asetti tuon historiallisen mahdollisuuden stalinistis-chdanovistista sielun muokkauksen insinööritaidetta sofistikoituneemmin, mutta näki taiteen ensisijaiseksi sisällöksi aina yhteiskunnallisen ihmisen humanistisen lunastuksen. Siksi realistisen taiteen ja kirjallisuuden lähtökohtana oli oltava ihmisen "normaalin käsite", ${ }^{93}$ jonka suhteen venäläinen formalismi, modernismi, surrealismi, kaikki ihmisyyden normaalin sisällön tehtävän esittämisestä poikkeavat esteettisen muodon kokeilut ilmenivät psykopatologisina pakkomielteinä. Normalisoivan vallan keskeiseksi kriitikoksi myöhemmin noussut Foucault pakenikin Lukácsin virallista tapaamista päästäkseen Budapestin taidemuseoon katsomaan Édouard Manetin groteskiksi koettua maalausta Pahan kukkien Mustasta Venuksesta, tuosta Baudelairen epähumaania estetiikka ilmaisseen dekadentin runouden "mulattihuora" muusasta, Jeanne Duvalista. Bataille, joka oli 30-luvulla Acephalos-lehdessään kritisoinut Moskovassa "moraalisesti murtunutta" Lukácsta Nietzschen ja fasismin estetiikan yhdistämisestä, oli tarkastellut 50-luvulla juuri Manet'ta ensimmäisenä maalaustaidetta puhtaana maalaustaiteena harjoittaneena modernina maalarina. Bataillen mukaan modernin taiteen kaikista muista arvoista erotettu oma olemassaolo ruumiillistui juuri vuonna 1857 valtavan moraalis-esteettisen skandaalin nostattaneessa ja kaikkien aikaisempien Venusten ruumiit valkoisen karkeassa esityksessään profanoineessa Manet'n Olympiassa. Tuon valkean alastoman ruumiin puhtaan läsnäolon herättämä "pyhä kauhu" merkitsi Bataillelle modernin estetiikan perustavaa syntymää, ”jossa hiljaisuus hallitsee syvällisesti [...] ja taide ottaa sen paikan, joka aikoinaan - kaikkein kaukaisimpinakin aikoina - oli pyhää ja majesteetillista."95

Myös Foucault'lle Manet oli maalaustai- 
teen omalakisen kumouksen aloittaja, mutta ennen kaikkea katkoksen (rupture) kautta, jonka tämä aiheutti renessanssista lähtien länsimaista maalaustaidetta hallinneeseen representaation läpinäkyvyyden illuusion ideaaliin. Vaikka Foucault myönsi olevansa taidehistoriassa amatööri, hän luennoi SA:n jälkeen Tunisiassa maalaustaiteen historiasta ja suunnitteli Pimeys ja Pinta työnimellä teosta maalaustaiteen historiasta renessans-

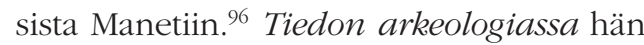
pohtikin erityisen maalaustaiteen arkeologisen analyysin mahdollisuutta, joka tutkisi tietyn aikakauden taiteellisen esityksen käytännöissä ilmenevää tiedollista rakennetta. ${ }^{97}$ Tässä Foucault'n arkeologisessa näkemyksessä Manet ei ollut vain impressionististen tekniikoiden edelläkävijä vaan impressionisteja radikaalimpi taiteellisen esityksen rakenteellisen muutoksen ilmaisija, joka siitä huolimatta, että maalasi edelleen esittäviä tauluja, ei pyrkinyt häivyttämään tauluissaan esityksen aineellisia ehtoja vaan sitoi ne mukaan esitykseen. Manet löysi näin maalauksen esitystä aineellisessa olemassaolossaan kehystävän taulukohteen (tableau-objet) esityksen itsensä elementtinä. Olympian aiheuttama esteettinen skandaali juontuikin Foucault'n mukaan osaksi Venuksen alastomuuden esille tuovasta taulun valaistuksesta. Olympian alastomuus ei Titianin renessanssi-Venuksen tapaan paljastunut Venukselle ja taulun katsojalle yhteisessä harmonisessa valossa, vaan se riisuttiin paljaaksi väkivaltaisen keinotekoisella kylmällä valolla, joka näytti iskevän tauluun katsojan paikalta ja tekevän katsojasta osallisen tuohon valkeaan alastomuuteen. ${ }^{98}$ Manet'n Olympia oli Titianin Venuksen tietoinen moderni kahdennus, ja Manet ei ainoastaan maalannut tietoisessa suhteessa kankaan ja esitystilan aineellisiin rajoihin vaan samalla kiistävässä suhteessa koko aikaisempaan maalaustaiteen perintöön, modernin taidemuseon mahdollistamaan taiteen itsenäiseen tiedolliseen kokemukseen.

Manet-kirjassaan Bataille viittasikin Malraux'n ajatukseen museoiden luomista maalauksien kokoelmista "ainoana aikam- me pystyttämänä katedraalina". ${ }^{99}$ Massiivisessa taiteen psykologiassaan Malraux oli korostanut juuri taideteokset toistensa kanssa rinnastavien ja muista tehtävistään irrottavien taidemuseoiden merkitystä modernin taiteen uutena puhtaasti taiteellisen kokemuksen tilana, joka "olemattomuuden yöhön katoavan" traagisen ihmisen maailmassa mahdollisti tuon "syvän yhteyden, joka olisi muuten hävinnyt Jumalten kadotessa". ${ }^{100}$ Taideteosten valokuvakopioiden leviämisen mahdollistaman kuvitteellisen museon (Le Musée Imaginaire) käsitteessään Malraux levitti tuon taiteen katedraalin koko ihmiskunnan taiteellisen kuvittelukyvyn kasautumien ja rinnastusten heterogeeniseksi tilaksi. Esteettisessä loistossaan se lunasti myös niiden kulttuurien luomukset, jotka eivät tunteneet koko taiteen ajatusta, ja sovitti yhteiseen loistoon aikoinaan toisiaan vastaan taistelleet henget. Malraux'n esteettisessä "uskonnossa" taiteen aika ei ole sama kuin historiallinen eletty aika, ja silti "menneisyyden merestä nouseva taiteen valtaisa alue ei ole ikuinen eikä ulkoinen historialle [...] Sen menneisyys ei ole jo taakse jätettyä aikaa, vaan raskaana mahdollisuudesta, se ei edusta väistämätöntä vaan yhtyy aikakausiin vielä syntymättömän tavoin."101 Jumalan luomistyön sijaan tuo taiteen universaali katedraali viittasi ainoastaan ihmisen universaaliin luovaan kykyyn, jolla tämä luonnossa kuolemaan tuomittu olento haastoi kohtalonsa ja ylitti omassa kuvittelukyvyssään jumalten luoman maailman. "Kaikkein loistavimmat ruumiit eivät makaa haudoissa."102 Kommentoidessaan tulevan kulttuuriministeri Malraux'n esteettistä humanismia, eletyn ruumiin fenomenologi Merleau-Ponty huomautti taas kriittisesti, että "vaikka tietoisuutemme maalauksesta maalauksena perustuu museoon", ${ }^{103}$ ei tuo "nekropoliksen mielenylennys ole taiteen todellinen ympäristö" ${ }^{104}$ vaan tarjoaa ainoastaan melankolisen langenneen kuvan taiteilijan luovan eleen elävästä historiallisuudesta. "Hegel oli museo", ${ }^{105}$ ja Malraux'n pyrkimys koota koko historiallisen hengen liike yhteen totaaliseen museoon oli Malraux'n 
juhliman ihmisen universaalin luovan eleen historiallisen elävyyden peittävää pseudohegelismiä. Pohjimmiltaan museo on "kuoleman historiallisuutta", ${ }^{106}$ joka ei koskaan lunasta Cézannen luovan käden elettä sen pyrkimyksessä toteuttaa olemassaolon esittämisen loputon tehtävä.

Arkistojen pölystä uutta ajattelua etsinyt Foucault, joka vielä 60-luvulla viihtyi vapaaajallaankin katumielenosoituksia paremmin taidemuseoissa ja hengellisestä sisällöstään tyhjentyneissä ja enää vain esteettisesti loistavissa katedraaleissa, näki museot Malraux'n tapaan äärettömyyteen kasaantuvan "ajan heterotopioina". ${ }^{107}$ Hän ylisti 1800luvulla syntyneiden museoiden eroa juuri aikaisempiin elävän yksilöllisen valinnan makua edustaviin kokoelmiin niiden pyrkimyksessä koota ajan ulkopuolelle tiettyyn tilaan eräänlainen kaikkien aikakausien ja makujen yleinen arkisto. Tuon arkiston ansiona ei ollut kuitenkaan lunastaa Malraux'n juhlimaa kaikille ihmisille yhteistä luovaa elettä vaan ennemminkin vapauttaa kuvittelukyky universaalin ihmisyyden oletuksesta. Foucault'n yleinen arkisto ei nimittäin heijasta ihmisyyden universaalia elettä eikä sulkeudu ajan yhteen keräämään totaaliseen museoon vaan avautuu arkistojen äärettömyyteen, joka itsessään muodostaa uuden kuvittelukyvyn tiedon tilan. Nuori Foucault oli nähnyt vapaan kuvittelukyvyn tilan avautuvan mielikuvituksen transsendentaalina ehtona toimivassa heterogeenisessä unen kokemuksessa, jonka subjekti "on uni itsessään, uni kokonaisuudessaan". ${ }^{108}$ Nuoren Foucault'n unen ja runouden dialektiikassa mielikuvitus vapautui vieraantumisestaan mielikuviin unikokemuksen eksistentiaalisessa liikkeessä, jonka runoilija vuorostaan lunasti kielikuvien ilmaisussaan. Transsendentaalinen "kuvittelukyvyn antropologia" lunastettiin näin inhimillisesti konkreettishistoriallisessa "ilmaisun antropologiassa". "Sillä olemassaolon murheellisuus on kirjattu aina vieraantumiseen, ja onnellisuus empiirisessä järjestyksessä voi olla vain ilmaisun onnellisuutta." 109 Tiedon arkeologian oli kuitenkin tarkoitus vapauttaa sekä tieto että mielikuvitus tästä antropologis-empiirisen onnen vieraantumisen dialektiikasta, sen jälkeen kun strukturalismi oli löytänyt uuden symbolisen järjestyksen tilan subjektin kuvitelmien ja tälle annetun todellisuuden välistä. "Kuvitteellinen ei muodosta itseään todellista vastaan tai kompensoidakseen sitä, se leviää merkistä merkkiin, uudelleen sanotun ja kommentaarin välissä." ${ }^{110}$ Nyt Foucault ylisti Manet'ta ja Flaubertia modernin ainutkertaisen kuvittelukyvyn aukaisijoina. Tuo kuvittelukyky ei asustanut transsendentaalisen subjektin maailman konstituutiossa, eikä sen transsendentaalinen ehto ollut enää tietoisen subjektin ylittävässä unikokemuksessa vaan arkistojen aarteiden avaamassa tiedon kokemuksessa. "Kuvitteellinen asustaa kirjan ja lampun välissä [...] unelmoidakseen ei tarvitse sulkea silmiä vaan lukea."111 Niinpä Flaubert ei löytänyt Pyhän Antoniuksen kiusauksia käsittelevän romaaninsa huimia visioita unistaan vaan kirjastojen arkistoista. "Flaubert oli kirjastolle sitä mitä Manet oli museolle. He kirjoittivat ja maalasivat perustavassa suhteessa maalattuun ja kirjoitettuun tai paremminkin siihen mikä maalauksessa ja kirjoituksessa säilyi määrittämättömän avoinna. He synnyttivät taiteensa siellä missä arkisto muodostuu." ${ }^{112}$ Heille arkistojen kokemus ei ollut melankolinen menetetyn elävyyden rappion kokemus, josta modernia museon aikakautta niin hanakasti syytettiin, vaan kokemus, joka yhdisti tästä lähin jokaisen maalauksen kankaiden loppumattomiin pintoihin ja jokaisen kirjan kielen määrittämättömään muminaan. Kyse oli kuvittelukyvyn heterogeenisestä tilasta, joka ei löytänyt rajojaan "äärellisen" ihmisen maailmankokemuksesta vaan avautui kaikkien mahdollisten maalausten ja kaikkien mahdollisten kirjojen loputtomaan mielikuvitukseen.

Surrealistimaalari René Magrittelta ei jäänytkään huomioimatta SA:n kuvaaman renessanssijärjen kuvitteellinen rikkaus, ja hän kirjoitti heti kirjan ilmestyttyä Foucault'lle, kuinka tämä oli löytänyt samankaltaisuuden ja samanlaisuuden käsitteiden kautta omalle tiedollemme täysin vieraan renessanssin 
maailman. Foucault ei kuitenkaan ollut kuvitellut tuota tiedon omituista fantasiaa omasta päästään vaan löytänyt sen nykytietämyksen "hylkäämän" tietämyksen tiedonarkistojen järjestyksestä. Magritte, jolle maalaustaide oli erityinen ajattelun muoto, oli itse pitänyt New Yorkissa näyttelyn nimellä Sanat ja asiat ja oli innokas käymään keskustelua Foucault'n kanssa maalausten ja ajattelumuotojen suhteista. Taiteilija kuoli kuitenkin seuraavana vuonna, ja Foucault julkaisi tämän muistosanoiksi sanottujen ja näkyvien asioiden eroa korostavan Tämä ei ole piippu -tekstin Magritten maalauksista. Foucault'lle erityisesti Magritten piippumaalauksissa kyse oli "puretun kalligrafian"113 sirpaleista muodostuvasta tutkimuksesta, joka nosti Maigritten Kleen ja Kandiskyn rinnalle maalaustaiteen klassisen representaation purkajaksi. ${ }^{114}$ Foucault käytti hyväkseen Magritten kirjeissään korostamaa eroa ajattelun samankaltaisuuden (ressemblance) ja asioiden samalaisuuden (similitude) välillä ja esitti samankaltaisuuden hallitsevan representaatiota ja samalaisuuden taas kiertävän loputtomasti samanalaisesta samanlaiseen. Magritten surrealismi vapautti tuon samanlaisuuden leikin samankaltaisuuden vaateesta ja yhdisti maalaustaiteen samaan samanlaisuuden simulacrumin "kauan sitten kadotettuun kokemukseen", 115 jonka Pierre Klossowskin kirjoitus oli vuorostaan löytänyt kristinuskon arkistojen eskatologisen kielen kokemuksesta. Kristillisyyttä kiusaavassa kokemuksessa ihmisen lopussa palaavasta puhtaasta sanasta tuo sana nimittäin uhkasi ilmaantua todellisen puhtaan sanan (Kristus) ja sen kanssa samanlaisen pelkän sanan (anti-Kristus) leikin loputtomana simulacrumina. Kristillisyys antoi tuolle simulacrumin tilalle kiusaavan demonin lumon, kun taas taiteen modernit katedraalit löysivät siitä ainoan todellisuutensa.

Vaellellessaan vuonna 1963 Espanjan luentomatkallaan noista katedraaleista kenties kuuluisimmassa, Madridin Pradomuseossa, Foucault pysähtyi ihailemaan Diego Velázquezin mestariteosta, joka jo barokkimaalari Luca Giordanon mukaan edus- ti maalaustaiteen teologiaa ja joka Manet'n mukaan oli lähimpänä puhdasta maalaustaidetta. Hovinaiset nimellä nykyään tunnetulla taululla ei olekaan koskaan ollut varsinaista erisnimeä, ja alunperin tuo prinsessa Margaritan hahmon ympärille keskittyvä maalaus oli listattu varastoon perhepotrettina (El Cuadro de la Familia). Sittemmin sitä on pidetty myös hovimaalariksi nousseen Velázquezin omakuvana. Mutta mitä taulu itse asiassa esittää? Taulussa on esitetty sekä hovimaalari itse taulun maalaamisen hetkellä että myös kaikki ateljeen neliömäisessä tilassa olevat kohteet ja henkilöt itse maalaus mukaan lukien. Kaikki ovat näkyvillä ja nimettävissä, kuten klassinen representaatio vaatii. Kuitenkin se, mitä maalari maalaa ja jolle taulun esitys esittäytyy, se, mikä näin samalla jäsentää koko taulun kuvaamaa esitystä, koska kaikki taulussa ovat kääntyneet sitä katsomaan, näyttäytyy vain taulun ulkopuolisen paikan heijastuksena, sen takakeskiön peilistä tuijottavien kasvojen utuisena heijastuksena. Tosin nekin on helppo tunnistaa ja nimetä hallitsijapari Filip IV:ksi ja Mariana Itävaltalaiseksi. Mutta jos unohdamme erisnimet ja klassisen ihanteen sanojen ja näkyvän vastaavuudesta, eikö peilistä voisi yhtä hyvin paljastua Velázquezin kasvot Escorialin salissa tai Foucault'n hämmentyneet kasvot Prado-museossa? Velázquez on kuitenkin maalannut itsensä (maalarin) näkyviin maalaukseen ja myös satunnaisen katselijan taulun takalaitaan huoneen oven kynnykselle. Mietiskellessään taulua Pradossa, Foucault huomasi, että sen moneen kertaan analysoidun representaation leikin nerous oli tehdä eräänlainen puhdas representaatio itse klassisesta representaatiosta, jossa suvereenin paikka, esityksen ilmaantumisen ehto ja kohde, voi esittäytyä vain poissaolonsa heijastuksena, pelkkänä representaationa. Moderni ajattelu haluaisi sijoittaa tuohon näkyvän ja näkymättömän risteyspaikkaan, samanaikaisesti läsnä ja poissa olevan äärellisen ihmisen hahmon, joka käsitteenä saattaisi yhdistää niin Filip V:ttä historiallis-empiirisenä kohteena, omaa kuvaansa maalavan Veláz- 
quezia toimivana subjektina tai Foucault'ta maalauksen kokevana katsojana, vaikka taulussa kaikki maalauksen esittämät hahmot loistavat tuon representaation itsensä suvereenisuudessa.

Voittoisan porvariston katkaistua suvereenin kaulan, se kuitenkin halusi 1800-luvun porvallis-pömpöösissä klassisismissaan, että esityksessä loistaisi juuri ihmisen oma voittoisa historiallisuus, kuten Foucault'n mukaan tapahtui myös vastaavassa Stalinin proletariaatin humanistisessa "uusklassisismissa”. ${ }^{116}$ Malraux olikin nähnyt Moskovan antamassa tuomiossa Picassolle stalinismin varsinaisen vaaran koko eurooppalaiselle kuvittelukyvylle, mutta kun Picasso maalasi omat 58 Velázquezin esityksen rytmillä, väreillä ja liikkeillä leikkivää modernia versiota tuosta taiteen mestariteoksesta, eivät nämä aiheuttaneet samanlaista skandaalia kuin Stalinin epähumaani esitys. Antihumanistisessa estetiikassaan Foucault tosin suosi modernin taiteen luovaksi neroksi julistetun Picasson sijaan modernin ajan Velázquezina näkemäänsä Paul Kleetä, joka tutki representaatiota itseään tuomalla näkyviin maalauksen kaikki perustavat elementit (eleet, värit, hahmot) ja ehdot sen itsensä hajaantuneessa aineellisessa ja juoksevassa pinnassa. ${ }^{117}$ Mutta vaikka Hovineidot-taulu on tullut hallitsemaan koko SA:n luomaa mielikuvaa klassisesta taulukon kautta järjestyvästä tiedosta, ei SA analysoi sen enempää renessanssin kuin Manet'n tai Kleen maalauksia. Itse asiassa teoksen ei alun perin pitänyt sisältää edes Foucault'n jo aikaisemmin taidelehdessä julkaisemaa ekfrasista Hovineidoista, jota hän piti tiedonhistorialliseen teokseensa esitystavaltaan liian lyyrisenä. ${ }^{118}$ Elämän, tuotannon ja kielen diskurssien analyysin sivussa SA kuitenkin piirsi eräänlaisen taaksepäin katsovan arkeologian modernin kielen itsensä olemassaolon voiman myöntävästä lyyrisestä kirjallisuudesta. Foucault intoutuu itsekin sanoilla leikkivään runollisempaan ilmaisuun kirjoittaessaan klassisen representaation rajoilla kohti tuota kirjallisuuden itsensä kokemusta kurottautuvista Don Quijoten sekä Justinen ja Julietten seik- kailuista. Hulluuden historiassa Foucault oli kirjoittanut, kuinka renessanssissa vielä itsenäisen äänen tiedon kokemuksessa omannut klassisen järjen toiseus soi modernissa enää vain fiktiivisen kielen lyyrisessä protestissa. ${ }^{119}$ SA:ssa taas modernissa kirjallisuudessa uudestaan löydetty kielen elävän ja itsenäisen olemisen kokemus on ainoa asia, joka muistuttaa enää epäsuorasti maailman samankaltaisuuksien tulkintaan uponneen renessanssijärjen kokemusta kielestä maailman itsensä proosana.

\section{MAAILMAN PROOSASTA PROOSAN MAAILMAAN}

Enemmän kuin pelon tunteessamme olemattomuutta kohtaan, Jumalan kuolema kumajaa syvästi kielessämme, hiljaisuudessa, joka on sijoittunut sen perustaan ja jota yksikään teos, ellei se ole pelkkää lörpöttelyä, ei voi peittää. (Michel Foucault)

"Siten Bacchus, muusien johtaja näyttää mysteereillään, näkyvän luonnon merkeillä näkymättömän jumalan asiat", ${ }^{120}$ kirjoitti Giovanni Pico della Mirandola teoksessaan Ihmisen arvokkuudesta. Foucault ei viitannut SA:ssa tuohon renessanssihumanismin perustekstiin, mutta hän väitti, ettei renessanssin tieto rakentunut ihmisen merkityksellistävän toiminnan perustalle vaan maailman näkyvien merkkien samanlaisuuden tulkintaan asioiden itsensä kirjoittamassa maailman proosassa. Estetiikan luennoillaan Hegel oli käyttänyt maailman proosa ilmaisua luonnehtimaan äärellisyyden ja epävakauden maailmaa, jossa henki (sanat) ei ollut vielä vapautunut luonnosta (aineesta). ${ }^{121}$ Merleau-Ponty taas oli suunnitellut tuonnimistä teosta modernin kirjallisuuden luomasta maailman kokemuksesta. ${ }^{122}$ SA puolestaan kuvasi sillä sanat ja asiat samankaltaisuuden kautta yhteen kutonutta tiedonjärjestelmää, jossa kieli ei ollut maailman asioiden osoittamisen keinotekoinen järjestelmä vaan itsessään maailman hahmojen kanssa yhteenkietoutunut maailman aineellinen osa. Maailma avautui siinä eräänlaisena toisiinsa viittaavien samankaltaisuuksien jälkien suurena kirjana. Samalla kirjoitus sai ehdotto- 
man etusijan tuossa tiedon järjestelmässä, joka koostui merkkien samankaltaisuuksien loputtomasta tulkinnasta. Jacques Derrida oli kritisoinut Foucault'n Hulluuden historiaa sen historiallisen strukturalismin pyrkimyksestä tehdä itse historiallisuuden alkuperässä olevasta hulluuden hyberbolan jatkuvan ulossulkemisen rakenteesta erityinen historiallinen tapahtuma. ${ }^{123}$ Juuri SA:n ilmestymisen alla Derrida taas julkaisi artikkelin kirjoituksen tieteestä, grammatologiasta. ${ }^{124}$ Siinä hän tarttui Ernst Robert Curtiuksen huomautukseen renessanssin kirjametaforan etuoikeuttamien kirjoituksen ja kirjainmerkkien väheksymisestä antiikissa ja valistuksessa ja radikalisoi tämän väheksymisen koskemaan koko länsimaista ajatteluperintöä. ${ }^{125}$ Derrida syytti länsimaista perinnettä kokonaisuudessaan elävän puheen läsnäolon suosimisesta kirjoitettujen merkkien kätkemien jälkien sijaan. Derridan mukaan silloinkin kun kirjalle ja kirjoitukselle oli annettu keskeinen asema, tämä sisälsi ajatuksen jumalallisen tai luonnollisen itselleen läsnäolevan totuuden puheen kirjoituksen etusijasta aineellisten merkkien piirtämien jälkien suhteen. ${ }^{126}$ Foucault taas kirjoitti, kuinka renessanssin suuri metafora kirjasta oli vain käänteiskuva tapahtumasta, joka pakotti kielen juuri aineellisessa muodossaan sijaitsemaan kasvien, yrttien, kivien ja eläinten rinnalla. Samalla kirjapainotaito, sellaisen kirjallisuuden synty, jota ei oltu tarkoitettu äänen lukemiseen, tekstien ja kirjoituksen tulkinnalle annettu etusija uskonnollisen perinnön välittämisessä ja niin edelleen todistivat Foucault mukaan suuresta murroksesta länsimaisessa kulttuurissa: "Kirjoituksen ensisijaisena luonteena on vastedes olla kirjoitettua. Puheen äänteet muodostavat siitä ainoastaan ohimenevän ja epävarman tulkinnan."127 Renessanssin maailman proosassa "puheen perustana on kirjoitus, joka ruumiillistuu maailman kanssa"128. Itselleen läsnä olevan puheen sijaan renessanssin aktuaalinen tulkintateoria edellytti ajatuksen "alkukantaisen Tekstin suvereniteetista", ${ }^{129}$ jonka paluuta jokainen diskurssi samalla lupaa ja lykkää. Se edel- lytti myös ajatuksen erityisistä aineellisista tunnusmerkeistä (les signatures), ei niinkään Jumalan sanan kätkeminä ilmauksina, vaan tämän asettamina puumerkkeinä, ajan haalistamina luomistyön kirjallisina allekirjoituksina. Ilman näitä yhteensopivuuden, kilvoittelun, analogioiden ja sympatioiden samanlaisuuden leikin kautta jäsentyvä renessanssin tieto, jossa kielet ja sanat olivat "maailman kanssa pikemminkin analogiakuin merkityssuhteessa", ${ }^{130}$ olisikin karannut itseltään puhtaaseen samanlaisuuksien loputtomaan simulaatioon.

Tuo tieto muuttuikin heti fantasiaksi, kun sanat ja asiat erkanivat samankaltaisuuden siteistä ja sanojen tehtäväksi tuli nimetä asiat mahdollisimman läpinäkyvästi. Jokainen "puhe-esitys (oratio) sisältää samalla ne mitä merkitään (significantur) ja ne joilla merkitään (significant), siis asiat ja sanat (rebus et verbis)", ${ }^{131}$ oli tärkeistä asioista kauniisti puhumaan opettanut antiikin retoriikka todennut. Quintillianus tosin myös kehotti liittämään sanoista koetun huolen asioista huolehtimiseen. ${ }^{132}$ Vastaliikkeenä sanoille liiallisen painoarvon antaneelle ciceronismille asioiden painottamisesta tulikin uudella ajalla keskeinen retoriikan fantasioiden vastainen vaatimus ja "sanat ja asiat" muodostui iskulauseeksi yritykselle saada sanat vastaamaan mahdollisimman tarkkaan ei vain puhuttua asiaa vaan maailman asioiden heijastusta. Englannissa Scribleruksen kirjallisen piirin satiiri pilaili sittemmin tuolla Kuninkaallisen akatemian kielellisellä hankkeella ja Gulliverin retkissä Swift kuvaa Lagadon Suuren Akatemian oppineita, jotka halusivat poistaa kaikki sanat. "Koska sanat olivat vain esineiden (things) nimiä, tarjoutui se huojennuskeino, että kaikki ihmiset kuljettivat mukanaan ne esineet, joita kulloinkin keskustelussa tarvitsivat." 33 Foucault taas ilmoitti myöhemmin SA:n nimen viittaavan juuri tuohon klassisen ajan "suureen iskulauseeseen" ja korosti, ettei hän ollut kirjassaan pyrkinyt etsimään Don Quijoten kirjallisuushistoriallista totuutta tai merkitystä vaan halusi esittää tämän "pienenä komediana", satiiri- 
sena teatterina siitä merkkijärjestyksen tilan hajoamisesta, jonka uusi representatiivinen tiedonjärjestys halusi asettaa. ${ }^{134} \mathrm{SA}$ :ssa Foucault liittää kuitenkin tuon merkkien komedian juuri Don Quijoten asemaan kirjallisuuden itsensä kieltä tavoittelevana ensimmäisenä varsinaisena romaanina. Foucault'n opettajan Jean Hyppoliten Hegel-luennassa Don Quijote olikin esimerkillinen romaani runouden säilymisestä proosallisessa maailmassa, koska se asetti vastatusten uuden järjen riisuman maailman ja sankarin kohdetta vailla olevan mielikuvituksen. ${ }^{135}$ SA taas esittää sen komediana samankaltaisuudelle perustavan tiedon kohtaamasta pilkasta uudessa erojen ja identiteettien julmassa järjessä, jossa samankaltaisuuksien kuvittelukyky on siirretty tiedon perustasta sen marginaaleihin. Siirrettynä pois järjen keskiöstä se saattaa ilmaantua tuosta uudesta järjestä vapautuneena ainoastaan klassisen tiedonjärjestyksen vastalaidoilla, joko hulluuden epätotena hourailuna tai puhtaana runollisen sanan totuutena. ${ }^{136}$ Tiedon järjestyksen komediana Don Quijote ei olekaan vain uuteen proosalliseen aikaan eksynyt runollinen ritari vaan tiedon hahmo, liikaa vanhoja kirjoja lukenut ja kaikki ritarikertomusten fantasiat yhteen kerännyt renessanssin tietämys, joka ei enää uudessa tiedon maailmassa löydä totuutta asioiden samankaltaisuuksista. Tämä todesta tiedosta irronneen mielikuvituksen seikkailu voidaankin lunastaa enää kirjaimellisesti vain kirjallisen kirjaimen totuutena. Toisessa osassa tarina taittuukin itseensä ja hulluna pilkattu sankari löytää vihdoin totuutensa, nimittäin kun tämän hahmo tunnistetaan ja nimetään ensimmäisen osan fiktiiviseksi sankariksi, sen kirjalliseksi totuudeksi, jota sankarin on vastedes esitettävä uskollisesti.

Vastaavasti Foucault esittää Markiisi de Saden irstailujen näyttämöiden sijoittuvan klassisen representaation toiseen päähän, jossa Saden kieli kolkuttaa tuon representaation moraalisia ja esityksellisiä rajoja ja kääntää klassisen ajan hyveellisyyttä esittäneet kehitysromaanit halua itseään, sen totuutta kaikkein väkivaltaisimmissakin muodoissaan tavoitteleviksi tiedollisiksi tutkimuksiksi, mutta päätyy tuottamaan vain loputtomia ja pikkutarkkoja irstailuja nimeäviä kirjallisia esityksiä. Saden hahmot etsivät halun salaisuutta representatiivisessa kielessä ja löytävät vain representaatioita. Juliette tahtoo olla kaikkien mahdollisten halujen subjekti, mutta saattaa ilmaista halunsa vain tuottamalla loputtomia toistoja irstailujen esityksestä. Justine on tahtomattaan kaikkien muiden halujen määrittämätön objekti ja alkuperä, mutta tuntee tuon halun vain toisten siitä esittäminä jääkylminä representaatioina. Surrealismista lähtien ranskalaisen kirjallisuuden avantgarde oli nostanut Saden, tuon vallankumouksen vankilaan sulkeman ja epämoralismissaan hulluksi tuomitun aristokraatin loistamaan uudestaan kaikkia kirjallisen esityksen rajoja kyseenalaistavana kirjallisen vallankumouksellisuuden edelläkävijänä. Foucault taas halusi tavoittaa Saden kirjallisen vallankumouksen aseman suhteessa tiedon järjestyksen muutokseen. Samankaltaisuuden kuvittelun (Don Quijote) ja anonyymin halun (Juliette ja Justine, halun subjekti ja objekti) tieto löysi klassisessa representaatiossa totuutensa vain representaationa representaatiosta, kirjallisuutena. Varsinainen moderni kirjallisuus erityisenä oman olemassaolonsa muotona edellyttää kuitenkin perustavampaa irtaantumista representatiivisen kielen ylivallasta ja kirjallisuuden kirjoittamisesta suhteessa kokemukseen paljaasta ei-diskursiivisesta kielen olemisesta. Don Quijote ironisoi ritariromaaneja ja Sade hyveellisyyden romaaneja, mutta Foucault'lle ne jäivät vielä erillisiksi kirjoiksi. Flaubert taas ei kirjoittanut enää kirjoja tietyistä kirjoista vaan kaikista kirjoista, ja lopulta Mallarmé kirjaa vain fragmentteja tuosta mahdottomasta maailman itsensä ja paljaan runouden olemuksen ilmaisevasta Kirjojen kirjasta, jonka käsikirjoitus makasi tämän tyhjässä lipastossa yhdessä monen modernin väitöskirjan kanssa.

SA:n väitteen mukaan juuri klassinen pyrkimys tehdä sanoista läpinäkyviä representaatioita, tehdä niistä asiallisia erottamal- 
la ne omasta asiallisuudestaan, teki niistä läpinäkyvyydessään suvereeneja ja samalla ideaalista representatiivisesta kielestä maailman tietämisen muodon. Modernissa tiedon järjestelmässä sanat sen sijaan putoavat takaisin maailmassa sijaitsevan objektin arvoitukselliseen tiheyteen ja tiedon mielenkiinto suuntautuu nyt tuon maailmaan hajonneen kieleen tutkimukseen. Kielitieteilijöille sanoista ja kielestä tulee historiallinen maailmassa olemassa oleva asia. Formalistit haluavat tyhjentää nuo sanat erityisistä sisällöistään tutkiakseen näin niiden puhtaita muotoja ja tulkitsijat taas avata niiden historiallisen tiheyden löytääkseen niiden kätkemän merkityksen. Kirjallisuudessa tuo sanojen olemassaolo saatetaan kuitenkin kohdata puhtaan itseisarvoisesti pelkässä sanojen itsensä olemassaoloon viittaavassa puhumisen ja kirjoittamisen toimessa. Moderni kirjallisuus syntyy näin kielitieteen tiedon kiistävänä kahdennuksena, joka kuljettaa kielijärjestelmät ja kieliopit takaisin sanojen villin olemassaolon puhunnan voimaan. Se luo maailmassa olemassa olevien sanojen kautta tämän vastamaailmaksi oman proosan maailmansa, mutta sen maailmassa moninaistamat kirjalliset sanat eivät enää kätke alkuperäistä tekstiä vaan leviävät ainoastaan omassa tyhjyyden perustalla rakentuvassa rajattomassa ja päämäärättömässä puhunnassaan. Moderni kirjallisuus on siten oman todellisuutensa muodostava tiedon ja ajattelun muoto, jonka ilmaantuminen tapahtuu suhteessa modernin tiedonjärjestyksen tilaan. Vaikka antiikista asti on ollut kirjallisuudeksi kutsuttuja diskursseja, on SA:n mukaan puhtaasti omaan kirjallis-kielelliseen olemassaoloonsa viittaava kirjallisuus uusi asukas ajattelun maailmassa. Kyse ei siis ole mistä tahansa modernissa maailmassa kirjallisuudeksi kutsutusta merkkejä paperille raapustavasta kynäilystä vaan erityisestä kielen kirjallisen totuuden tutkimukselle omistetusta kirjallisuudesta.

KIRJALLISUUS ILMAN IHMISTÄ

Jos sanon "maailma on ihminen" saan aina synninpäästön, mutta jos sanon "asiat ovat asioita ja ihminen vain ihminen" minua syytetään heti rikoksesta ihmisyyttä vastaan. (Alain Robbe-Grillet: Kohti uutta romaania.)

"J'accuse". 23.2.1898 kirjailija Émile Zola tuomittiin julkisesta herjauksesta vuodeksi vankeuteen. Syynä oli Aamurusko-vaihtoehtolehdessä julkaistu, historian vaikutusvaltaisimmaksi nimetty lehtiartikkeli, jossa Zola asettui totuuden puhujaksi ja syytti Ranskan hallintoa rikoksesta yhteiskuntaa vastaan. ${ }^{137}$ Kirjailijan iskulause "syytän" kaikuikin huutona kaupunkien kaduilla modernin julkisuuden aamunsarastukseksi nähdyssä ja koko kansakunnan kiihkeään poliittiseen debattiin jakaneessa Dreufystapauksessa. Surrealistien suorittama Anatole Francen ruumiin häväistys ei myöskään ollut vain nuorten miesten pahennusta herättänyt taideproggis, vaan julkisen kirjallisuusdebatin aloittanut kokonaisvaltainen syytös Francen ja Zolan sukupolven ruumiillistaman edellisen vuosisadan kirjallisuusinstituution kykenemättömyydestä ottaa huomioon ensimmäisen maailmansodan avaaman uuden kokemusmaailman todellisuutta. Kirjallisuudella ja kirjoituksiensa kautta vaikuttavalla kirjailija-intellektuellilla olikin Ranskassa vahva perinne, samoin kuin tuossa perinteessä yhä uudestaan kirjallisuuden yhteiskunnallista roolia kyselevillä debateilla. Kirjallisuudentutkimus vuorostaan muodosti keskeisen tiedonmuodon humanistisessa ihmistieteiden traditiossa, jonka uudet strukturalististen ihmistieteiden teoriat ja menetelmät olivat haastaneet. Tuo haaste ei suinkaan hylännyt kirjallisuutta tai sen tutkimusta vaan halusi vapauttaa kummatkin lopullisesti vanhan humanismin ja traditionaalisen kritiikin käsitteistä.

Sanojen ja asioiden provosoima debatti ei ollutkaan vuoden 1966 ainoa julkisen kohun kynnyksen ylittänyt akateeminen keskustelu ihmistieteiden olemuksesta. Vuoden 1966 suuri kirjallisuusdebatti, jota verrattiin lehdistössä Dreyfusin tapaukseen, koski strukturalismista inspiroitunutta kirjallisuustiedettä ja nosti Roland Barthesin julkisuuden valokeilaan niin sanotun "uu- 
den kritiikin" keskeisimpänä edustajana. "Merkkien, symbolien ja representaatioiden sosiologian" ohjelmaa EPHE:ssä johtanut Barthes oli erottanut tietoisesti aikansa suuria teorioita hyväkseen käyttävän uuden kirjallisuuskritiikin viime vuosisadalta periytyvästä kirjailijan elämää ja tämän tuotantoa kirjallisuushistoriallisen positivismin kautta tutkivasta yliopistokritiikistä. ${ }^{138}$ Esseissään ranskalaisen klassisen tragedian klassisesta edustajasta, Jean Racinesta, Barthes oli halunnut lukea Racinen luomaa maailmaa topologisesti ja juhli tätä klassikkoa ikuisesti uusille merkityksille avoimena erilaisten tutkimusten kohteena. Racinen kirjallisen jäämistön teoreettinen häväistys sai sen institutionalisoituneen vartijan, Raymond Picardin, Racinen elämäkertaan ja tuotantoon erikoistuneen Sorbonnen professorin, tunteet kiehumaan. Uusi kritiikki vai Uusi huijaus -pamfletissaan Picard syytti uutta kritiikkiä ja erityisesti sen ruumiillistumaksi näkemäänsä Barthesia villeistä konstruktiivisista luennoista ja patologiseksi kokemastaan kielenkäytöstä ja puolusti samalla selkeäsanaista kirjailijan tarkoittamien kirjaimellisten merkitysten tutkimista. Barthes taas vastasi syyttämällä traditionaalista kirjallisuuskritiikkiä kyvyttömyydestä käsitellä kirjallisuustieteen varsinaista tutkimuskohdetta, joka ei koostunut kirjailijan kirjaimellisista intentioista vaan kirjainten muodostamista symbolisista merkityksistä. ${ }^{139}$ Uusille vaikutteille avoin Barthes olikin ollut puolustamassa antihumanistiseksi syytettyä niin sanouttua "uutta romaania" ja ollut sitten keskeinen teoreettinen vaikuttaja 60-luvun alussa perustetun uuden sukupolven kirjallisuuslehden $\mathrm{Tel}$ Quelin teoreettis-kirjallisille kokeiluille ja niin sanotulle "uudelle uudelle romaanille". Näille yhteistä oli ennen kaikkea pyrkimys päästä eroon vanhan porvarillisen romaanin psykologisista konventioista ja sen todellisuutta enää tavoittamattomasta vanhasta humanistisesta realismista kohti uutta asioiden ja kielen itsensä todellisuutta. Uuden romaanin "isäksi" nostettua Alain Robbe-Grillet'ä syytettiinkin asettumisesta asioiden puolelle ihmistä vastaan. Robbe-Grillet taas syytti humanismia "panantropiasta" ${ }^{140}$ pyrkimyksestä nähdä kaikki maailman asiat ihmisen moraalisiin syytöksiin vastaavina syytöksinä. Hän näki romaaniensa käsittelevän juuri ihmistä tämän merkityksellistävään katseeseen vastaamattomassa maailmassa, "joka ei ole sen enempää merkityksellinen kuin absurdi. Se yksinkertaisesti on. Se on siinä kaikkein uskomattominta." ${ }^{141}$ Vastaavasti ainoa merkitys Sartren vaatimalle kirjailijan sitoutumiselle oli kirjailijan "täydellinen tietoisuus hänen kielensä nykyisistä ongelmista, uskomus niiden ehdottamaan tärkeyteen, halu ratkaista ne sisältä käsin”. ${ }^{142}$

Tämä oli suora vastakohta Sartren heti toisen maailmansodan jälkeen luomalle vaikutusvaltaiselle kirjallisuusohjelmalle. Siinä Sartre oli vaatinut maailman kirjallisten negaatioiden taakse jättämistä ja suuntautumista historian tekemiseen. "Täytyy hylätä exiskirjallisuus ja aloittaa praxis-kirjallisuus." ${ }^{143}$ Dialektisessa suhteessa lukijan vapauden kanssa kirjailijan on pyrittävä paljastamaan lukijalle "jokaisessa konkreettisessa tilanteessa hänen mahdollisuutensa rakentaa ja rikkoa, toisin sanoen hänen mahdollisuutensa toimia." 144 Kirjallisuus "luovan toiminnan vapaana tuloksena ilmentää täydellisesti ihmisenä olemista", ${ }^{145}$ ja tuota olemista kirjailijan on lähestyttävä kieltä välineenä käyttävällä selkeällä proosalla. "Kirjailijan tehtävänä on kutsua kissaa kissaksi. Jos sanat ovat sairaat meidän on parannettava ne [...] eikä mikään ole sen turmiollisempaa kuin kirjallisuudenlaji, jota luullakseni kutsutaan runolliseksi proosaksi. Siinä sanoja käytetään niitä ympäröivien outojen harmonioiden vuoksi." ${ }^{146}$ Kirjallisuuden valtakunta on proosa, runous kuuluu maalaustaiteen ja musiikin puolelle, koska runoilijat "kieltäytyvät käyttämästä hyväkseen kieltään" ja vetäytyvät pois kielestä välineenä ymmärtäen "sanat olioina eikä merkkeinä". ${ }^{147}$ Kirjoittaminen on kuitenkin aina kirjoittavan subjektin toimimista maailmassa ja näin aina kantaaottavaa siitä vetäytyessäänkin. "Lukutoimituksen ei tule olla mystillinen uskonyhteyden kokemus, ei liioin masturbaatiota vaan yhteistä toveruutta." ${ }^{148}$ Vaikka 
kirjoittamisen on vapauden nimissä kieltäydyttävä toimimasta "kommunistisen puolueen vahtikoirana", sen on taisteltava "sekä ihmisen vapauden puolesta että sosialistisen vallankumouksen puolesta". ${ }^{49}$ Tiedostavalle ja kantaa ottavalle kirjoittajalle sanojen on oltava "kesytetyt; runoilijalle ne ovat jatkuvasti luonnontilassa". ${ }^{150}$

Kun SA julisti modernin kirjallisuuden löytäneen uudestaan sanojen villin olemassaolon ja ennemmin korvaavan kuin vahvistavan kielen merkityksellistävää toimintaa, se ei siis viitannut Sartren vaatimaan praxis-kirjallisuuteen. Se viittasi 60-luvulla sartrelaisen kirjallisuusnäkemyksen kiistävän ja juuri Satren "modernin kirjallisuuden sanojen syöväksi" tuomitseman runollisen proosan ja kielen teorioiden kautta kohti kirjallisuuden itsensä vallankumousta, vapautta ja välttämättömyyttä pohtivaan kirjallisuuteen. SA esittikin Mallarmén antaneen kielen itsensä olemassaolon vastaukseksi Nietzschen kysymykseen siitä, kuka kielessä oikein puhuu. Mallarmé oli nostettu ranskalaisissa keskusteluissa runoilijaksi par excellence, josta lähes kaikki johtavat ranskalaisajattelijat kirjoittivat niin eksistentialistisia, fenomenologisia, psykoanalyyttisia, strukturalistisia, dekonstruktiivisia ja jopa kyberneettisiä ja termodynaamisia analyyseja. ${ }^{151}$ 60-luvun Mallarmé-debateissa Foucault nousi kuitenkin puolustamaan strukturalististen, psykoanalyyttisten ja dekonstruktiivisten kriitikoiden psykologisoivaksi ja sensualistiseksi haukkumaa J. P. Richardin temaattista ja kokonaisvaltaista Mallarmé-tutkimusta. Foucault katsoi Richardin löytäneen juuri arkistojen sisältämän pysähtyneen kielen (langage stagnant) tutkimuksesta uuden alueen kirjallisuudentutkimukselle, jossa Mallarmé ei viitannut vain nimissään kiertävien tekstien (langage circulant) formaaliin kieliopilliseen subjektiin tai ne kirjoittaneeseen tiheään psykologiseen subjektiin vaan näiden välissä sijaitsevaan rajoiltaan epäselvään "kokemukseen, henkeen tai olemassaoloon". ${ }^{152}$ Kysymys ei ollut sen enempää tekstin rakenteesta kuin kirjailijan sieluntilasta vaan kirjallisuuden kokemuksesta puhuvan subjektin suhteena erillisenä ja itsenäisenä olemassa olevan kielen arvoitukselliseen olemisen tapaan. ${ }^{153}$ Sarten mukaan taas Mallarmé oli mystifioinut tuon kokemuksen. Tämä oli kyllä suuri runoilija, mutta sellaisena Nietzschen viimeinen ihminen, joka "tapettuaan Jumalan omalla kädellään etsi edelleen jumalallista hyväksyntää". ${ }^{154}$ Mallarmé ei tyytynyt proosalliseen inhimillisen vapauden kommunikaatioon ja maailman merkityksellistämiseen vaan etsi paradoksaalisesti lunastusta sanojen aineellisuuden voimattomasta voimasta. Myös Bataille oli edustanut Sartren mielestä paradoksaalista jumalan kuoleman jälkeistä uutta mystiikkaa ja Spinozan kalpean panteismin järjestelmää vastaavaa "pimeää panteismia". ${ }^{155}$ Muistoesseessään Bataillelle Foucault taas ylisti tätä Kantin jälkeisenä kokemuksen rajojen ajattelijana, jolle kirjallinen transgressio oli itseensä suuntautunutta profanaatiota vailla positiivista pyhää olevassa maailmassa, rajattoman rajan (illimité de la Limite) hallitsemisen kokemusta. "Jumalan kuolema ei palauta meitä rajalliseen ja positiiviseen maailmaan, vaan rajan kokemuksessa aukeavaan maailmaan, joka synnyttää ja purkaa itsensä trasgression liiallisuudessa."156

Tel Quelin kirjallisuuspiiri, joka näki kirjallisten konventioiden murtamisen itsessään kulttuurista järjestystä ravisuttavaksi kumoukselliseksi toiminnaksi, olikin nostanut Bataillen ja tämän sodan jälkeen perustamassa Critique-lehdessä kirjoittaneet Maurice Blanchot'n tapaiset kirjailijat Sartren, Malrauxin ja Camusin varjosta modernin kirjallisuuden keskeisiksi edustajiksi. Vuonna 1966 ilmestyikin Maurice Blanchot'n tuotantoon keskittyvä Critiquelehden erikoisnumero, johon myös Foucault kirjoitti tuosta nuoruutensa suuresta kirjallisesta sankarista. Kirjallisuuden olemassaolon ehdoista kiinnostunut ja kirjallisuuden itsensä ontologiaa herkeämättä tutkinut Blanchot oli samalla piilottanut lähes täysin oman henkilönsä julkisuudelta.

Nähtävästi taide oli ammoin jumalten kiel- 
tä [...] taide jumalten paettua jää jumalten poissaolon ja puutteen kieleksi [...] ja muuttuessaan poissaolon poissaoloksi ja unohdukseksi taide pyrkii muuttumaan omaksi läsnäolokseen - ensi sijassa tarjoamalla ihmiselle keinon tunnistaa oma itsensä ja olla mieliksi omalle itselleen. Tässä vaiheessa taidetta kutsutaan humanistiseksi [...] Taide saa taiteilijan hahmon, taitelija saa kaikkein yleisimmässä mielessä käsitetyn ihmisen hahmon. Taide ilmaisee itseään siinä määrin kuin taiteilija esittää ihmistä, eikä hän ole ihminen vain taiteilijana. ${ }^{157}$

Blanchot ei halunnut esittää sen enempää taiteilijaa kuin ihmistä vaan tutkia taiteen samalla pakottavaa ja olematonta olemusta. Näin hän tarjosi vastakuvan Sartren ihmistä esittävälle kirjailija-intellektuellille. Samaan aikaan Blanchot'n kirjallisuuskäsitys oli sovitettavissa uuden kritiikin korostamaan kirjallisuuteen vailla subjektia. Blanchotille kirjallisuuden ainoa subjekti oli nimittäin siitä välittömästi kirjoittamisteossa katoava kirjoittaja ja ainoa objekti tuon tyhjyyden pohjalta syntyvät ja omaa tyhjää perustaansa kohden kurottauvat kirjallisuuden sanat, jotka eivät suinkaan lunastaneet vaan ennemmin tuhosivat heti paperille painautuessaan ne kirjoittaneen subjektin. Foucault'n mukaan Blanchot oli radikaali "ulkoisuuden ajattelija". ${ }^{158}$ Kreikkalaista totuutta oli järkyttänyt elealaisten "valehtelen"-paradoksi, kun taas "puhun"paradoksi koetteli koko modernia fiktiota. Tavanomaisen ajattelun mukaan modernin kirjallisuuden intransitiivisuus merkitsee sen ääretöntä itseensä samaistumista puhtaassa itseensä viittaavuudessa, mutta Blanchot'lla sisäistämisen sijaan kyse on enemmin kirjallisuuden itsensä jatkuvasta hajaantuneeseen ulkoisuuteen astumisesta, jossa "kirjallisuuden subjekti (se, joka puhuu siinä ja josta se puhuu), ei siten ole kieli positiviteetissaan vaan tyhjyys, jossa se saa tilansa, kun se lausuu itsensä 'puhun'paradoksin alastomuudessa". ${ }^{159}$ Vielä 70luvun kynnyksellä Foucault sanoi "parhaan määrityksen kirjallisuudesta"160 löytyvän Blanchot'n kirjallisuuden olemisen tapaa pohtivista kirjallisuusesseistä. "Blanchot on kirjallisuuden Hegel ja samalla Hegelin vastakohta."161 1800-luvun keskellä Hegel aktualisoi historian loputtomasta muminasta niin kreikkalaisen kuin keskiajan filosofian ja taiteen ajattelun aktuaalisina filosofisen ajattelun kokemuksina, siinä missä Blanchot taas aktualisoi kirjallisista suurteoksista kirjoittamisen kokemuksen. Mutta jos Hegelin mahtavassa historiallis-humanistisessa synteesissä nuo kokemukset koottiin yhteen sisäistetyn muistin muodossa, Blanchot löysi ne kirjoittajalle aina ulkoiseksi jäävässä arvoituksellisessa hajaantuneisuudessaan. Blanchot'n kirjallinen avaruus ei ole itsensä ympärille sulkeutuva totaliteetti, ei kirjoittajan taivaallinen lunastus vaan tätä ikuisesti piinaava kiirastuli. Kirjallisuuden oma avaruus, "joka ilmaantuu kaikkein arvokkaimpien kielellisten aarteiden museona, on itse asiassa ikuisen tulen polttorovio". ${ }^{162}$

"Kirjasto on tulessa"163 oli ollut Foucault'n yhä uudestaan ja uudestaan ajattelunsa yhteydessä lainaaman surrealistirunoilija René Charin johtaman vastarintayksikön koodisana. Foucault lainasi tuota lausumaa puhuessaan koko modernin kirjallisuuden jatkuvasti kirjallisuutta ja itseään vastaan käyvästä vastarinnasta. Foucault sanoikin kirjallisuudessa häntä kiinnostaneen juuri itsen kumouksen ja näki myöhemmin kirjallisuuden edustaneen hänelle toista, kokemuksellisempaa tapaa paeta ranskalaista subjektifilosofiaa. Siinä missä tätä nietzscheläistä olivat kiehtoneet formalistisissa tieteissä ja järjestelmissä fenomenologisen subjektin kyseenalaistavat apolloniset muodot, kirjallisuudessa häntä kiehtoi "järjestelmän rakentamisen sijaan henkilökohtainen kokemus" 164 tai paremminkin sen dionyysiset muodot, jotka pyrkivät kuljettamaan tuon kokemuksen eletyn rajoille kohti kielen itsensä olemassaolon avaamaa tyhjän perustan kokemusta ja näin ennemmin hajottamaan kuin varmistamaan kirjoittavan tai lukevan subjektin kokemusta. Vastaavasti Foucault'n 60-luvun kirjallisuusesseet olivatkin vähemmän teoreettis-strukturalistisia ja enemmän (anti)fenomenologisesti kirjallisuuden eletyn rajan 
kokemusta painottavia.

Valmistellessaan väitöskirjaansa hulluuden historiallisesta kokemuksesta Foucault oli toiminut Ranskan kulttuurikeskusten johtajana Ruotsissa, Puolassa ja Saksassa ja järjestänyt erityisesti kirjallisuutta koskevia keskusteluja ystävystyen muun muassa Robbe-Grilletin kanssa. Samalla kirjallisuuden kokemus tarjosi hänelle eräänlaisen vastadiskurssin hulluuden psykiatriselle kokemukselle. 60-luvun kirjallisissa kokeiluissa ja teoretisoinneissa Foucault ylistikin aina näiden antipsykologisia teemoja. Hulluuden ja runollisen inspiraation yhdistäminen on jo antiikista periytyvä teema, jonka moderni versio oli hulluuden ja runollisen kielen yhteyksien tutkiminen. Surrealistit olivat korostaneet kumpaakin ja vaikuttaneet erityisesti Jacques Lacanin ajatuksiin tiedostamattoman kielellisestä rakenteesta. ${ }^{165} \mathrm{La}$ Révolution Surréaliste juhlikin vuonna 1928 hysterian 50-vuotispäivää "1800-luvun lopun suurimpana runollisena löytönä", joka ei ollut patologinen tila vaan "kaikin tavoin ylin ilmaisun väline". ${ }^{66}$ Foucault taas itse vastusti hulluuden ja kirjallisuuden psykologista samaistamista ja vastaavasti Hörderlinin, Saden, Artaudin, Rousselin tai Nietzschen kirjallisen tuotannon palauttamista kirjoittajan psykologisiin patologioihin. Kirjallinen teos ei ollut koskaan "hulluutta, teoksen puuttumista". ${ }^{167}$ Modernissa puhdasta kielen kokemusta etsivä runous näytti kuitenkin puhuvan pohjimmiltaan tuon saman kielen perustavan tyhjyyden rajoilta ja perustalta, johon subjekti katosi hulluudessa tai josta Hörderlin sanat saattoivat vielä loistaa tämän itsensä jo kadottua Scardanellin takaiseen pimeyteen. ${ }^{168}$ Väitöskirjassaan Foucault oli itse asiassa halunnut historiallistaa tuon usein universalisoidun kokemuksen, ja teos saikin parhaimman vastaanoton kirjallisuuspiireissä. Vastaavasti Foucault kirjoitti koko 60-luvun alun intensiivisesti kirjallisuuskritiikkiä kirjailijoiden luomasta kirjallisen tilan kokemuksesta ja osallistui vetäjänä Tel Quelin järjestämiin kirjallisuutta ja romaanin olemusta käsitteleviin keskusteluihin, tosin kuulumatta varsinaisesti mihinkään uuden kritiikin tai kirjallisuuden koulukunnista. Salattuna kesäsuhteena hän kirjoitti nopeasti ainoan pelkästään kirjallisuutta ja yhtä kirjallista ajattelijaa koskevan analyysinsa surrealistien uudelleen kielen radikaalina kokeilijana löytämästä Raymond Rousselista. Tuo psykiatri Pierre Janet'n "potilasraukka”, joka eli täysin kirjallis-kielellisissä pakkomielteissään, avasi samalla itsenäisen kielen kokemuksen, jota ei voida palauttaa hänen patologiseen psykologiaansa vaan jossa tämän teokset ja hulluus asettuivat toisensa ulossulkevaan suhteeseen. Kirjailijana Roussel oli todellakin "kielen löytäjä, joka puhuu vain itsestään, kahdennuksessaan täysin yksinkertaisen kielen". ${ }^{169}$ Rousselin homonymioille perustuvat mielikuvitukselliset teokset muunsivat asioita sanovan kielen perustavan köyhyyden (sen, että sanoja on aina liian vähän ilmaisemaan kaikkia maailman asioita) sen luomiskyvyn rikkaudeksi, kyvyksi luoda pelkän toistonsa kautta "koskaan sanomattomia, kuulemattomia, näkemättömiä asioita". ${ }^{170}$ Kaikkia ajattelun imperatiiveja muuten väistelevä Foucault asettikin synonymialle vastakkaisen homonymian avaaman asioiden kuvittelukyvyn eräänlaisena ainoana toisinajattelun velvoitteena. "Kehitä oikeutettua omituisuuttasi", ${ }^{171}$ oli Foucault lainannut René Charia väitöskirjassaan, ja viimeisimpien kirjojensa motoksi hän valitsi jälleen Charin aforismin: "Ihmisten historia on saman sanan synonyymien pitkä jatkumo. Tämän kiistäminen on velvollisuus." ${ }^{172}$

Mutta kuten strukturalistisen järjestyksen kokemuksen myös kirjallisuuden kokemuksen suhteen SA ilmensi Foucault'n ajattelussa tuon kokemuksen eräänlaista joutsenlaulua. SA:n jälkeen kirjallisuus lakkaa olemasta Foucault'n ajattelun keskiössä ja nykyajattelun välttämätön kohde. Samalla hänen oma kirjoituksensa, joka varsinkin kirjallisuusesseissä on heittäytynyt itse kielen vietäväksi, muuttuu nyt perinteisemmäksi ja selkeämmäksi proosaksi. Kirjallisuus ei katoa kokonaan Foucault'n kiinnostuksen aiheista. Hän seuraa ja kommentoi sitä edelleen, mutta samalla pyrkii unohtamaan 60- 
luvun kirjallisuusesseensä lähes kokonaan ja vähättelemään koko kirjallisuuden roolia varhaisissa tutkimuksissaan. ${ }^{173}$ Sekä kirjallisuus että taide menettävätkin 70-luvulla perustavan roolinsa Foucault'n ajattelussa ja ajautuvat sen laidoille, missä ne ilmenevät vallan ja yhteiskunnallisten kamppailujen kysymyksille alisteisina. Jumalten haudasta eivät kaiu enää Scardanellin säkeet vaan "taistelun kumo". ${ }^{174}$ Vuoden 1969 Mitä on tekijä? -esitelmässään Foucault jo ilmoitti, että on turha toistaa "tyhjää väitettä tekijän katoamisesta. Vastaavasti ei myöskään riitä, että toistetaan loputtomasti väitettä Jumalan ja ihmisen toisiinsa kytkeytyvistä kuolemista." ${ }^{175}$ Mallarmésta lähtien tekijä on kyllä kirjallisuudessa lakkaamatta kadonnut, mutta Nietzschen kysymykselle siitä, kuka puhuu, ei riitä enää Mallarmén vastaus: kieli itse. Samalla Foucault kritisoi kirjoituksen asettamista tekijän paikalle tekstin alkuperään. Hän näkee tämän eleen nyt kirjoitusta ennemmin pyhittävänä kuin profanoivana toimintana, pyrkimyksenä muuntaa tekijän empiiriset ominaisuudet "transsendentaaliseksi nimettömyydeksi". ${ }^{176}$ Vuotta aikaisemmin vuoden 1968 kumoushuumassa Roland Barthes oli esseessään Tekijän kuolema halunnut asettaa tuon transsendentaalisen nimettömyyden tekstin alkuperän sijaan sen radikaalisti avoimeen päämäärään, kenen tahansa lukijan politiikkana. Barthes juhli kirjoitusta toimintana, joka vapautti jatkuvasti merkitystä rakenteista. Se oli siten tekstin teologian ja "lopultakin Jumalan ja hänen hypostaasinsa"177 kieltävää aidosti vallankumouksellista toimintaa. Tuon toiminnan, kirjoituksen moninaisuuden, yhteen keräävä paikka ei ollut kuitenkaan enää tekijä vaan sen hajauttava kaikista erityisistä ominaisuuksista irrallinen lukija. Itsevaltainen tekijä on kuollut, kauan eläköön demokraattinen kuka tahansa lukija! Foucault sen sijaan palaa esitelmässään tekijän käsitteeseen ja tutkii tuon käsitteen asemaa vallan kehikossa. Beckettin lausuma: "Mitä sillä on väliä kuka puhuu, sanoi joku mitä sillä väliä kuka puhuu", ${ }^{178}$ muodostaa kyllä aikakauden kirjoittamisen käytäntöä hallitsevan pe- riaatteen, mutta se on nyt ainoastaan lähtökohta tekijän käsitteen poliittis-historiallisen toiminnan tutkimukselle. Tekijää tai tämän puutetta ei pidä enää ymmärtää merkityksen lähteenä vaan käsitteenä, jolla tuomitaan, hallinnoidaan ja järjestetään maailmassa ilmenevän puheen ja diskurssien loputtomuutta. 70-luvulla Foucault asettaa myös kirjallisuuden kysymyksen diskurssien hallinnoinnin näkökulmasta. Samalla proosan maailma alkaa menettää kulttuurisen vastarinnan paikkaansa ja Foucault epäilee kirjoituksen kumouksellisen tehtävän jo hävinneen maailmasta. ${ }^{179}$ Sen sijaan kirjallisuuden kysymys kääntyy kysymykseksi siitä, miten kirjallisuus-funktio pyhittää maailman diskurssien moneudesta tiettyjä tekstejä kirjallisuusinstituutioksi. Nyt kirjallisuuden intransitiivisuus ei enää edusta ulkoisuuden ajattelua vaan suurimmalle osalle ihmisiä täysin yhdentekevää itsensä ympärille institutionalisoitunutta kirjallisuusdiskurssia, jossa avantgardekirjoittajia lukevat ainoastaan yliopisto-opettajat ja näiden oppilaat. Eräässä 70-luvun puolivälin haastattelussa Foucault jo ihmetteleekin, kuinka 60-luvulla saatettiin ajatella, että avatgardistinen kirjoittaminen itsessään olisi kumouksellista yhteiskunnallista toimintaa, ja väittää koko "raivostuttavan kirjoituksen teoretisoinnin, johon 60-luvulla osallistuttiin, olleen vain joutsenlaulua: kirjailijan kamppailua säilyttää poliittiset etuoikeutensa". ${ }^{180}$ Tuloksena ei Foucault'n mukaan ollut sen enempää kirjallista kuin poliittistakaan kumousta vaan ainoastaan keskinkertaista kirjallisuutta. 60-luvun kirjallisuuden pyrkimys hakea uusista tieteistä kirjallisuudelle sen kadottamaa arvovaltaa osoitti vain "suuren kirjailijan" hahmon kuolemaa ja tämän vallan korvaantumista teknis-tieteellisessä yhteiskunnassa tutkija-asiantuntijalla, jonka huolena ei ole enää "ikuisuuden laulu vaan elämän ja kuoleman strategiat". ${ }^{181}$ Foucault kieltää nyt kieleltä sille aikaisemmin antamansa perustavan roolin kulttuurissa ja ilmoittaa, että historiaa olisi tutkittava enemmin vallan kuin kielen rakenteiden muutoksien kautta: "Meitä tempova ja määräävää historiallisuus 
(l'historicitê) ei ole kielellinen vaan taisteleva. Se on vallan eikä mielekkyyden (sens) suhde." 182

Kirjoittaessaan Rebeyrollen maalauksista vangituista koirista Foucault toteaa: "Maalauksella on ainakin se yhteistä diskurssin kanssa, että tuodessaan esiin voiman, joka luo historiaa, se on poliittinen." 183 Tuo historiallinen voima on kuitenkin nyt Rebeyrollen maalausten suhteessa samaan aikaan maailmalla käytäviin vankilakamppailuihin. Foucault'n organisoiman vankilaolosuhteita tutkivan tiedonhankintaryhmän julkisen tiedotteen sanamuoto kopioikin Zolan kuuluisaa kirjelmää, "J'accuse" on tosin korvattu sanalla intolérable. "Sietämättömiä ovat oikeusistuimet, poliisit, sairaalat, hoitopaikat, koulu, asepalvelus, lehdistö, televisio, valtio." ${ }^{184}$ Robbe-Grillet'n mukaan taideteoksille riittää oma olemassaolonsa oikeutukseksi, vastaavasti Foucault kieltäytyy nyt asettamasta vastarinnan oikeutukseksi mitään muuta kuin sen oman olemassaolon. Tuo olemassaolo on vieläpä itsessään vallan ehto ja ilmaisija, sillä ei ole olemassa valtaa ilman vastarintaa ja valta ilmaisee itseään ainoastaan vastarinnan kautta. "Tarkkailla ja rangaista -teoksessa viittaan ainoastaan huonoon kirjallisuuteen", ${ }^{185}$ ilmoitti Foucault ajattelunsa uudesta suhteesta kirjallisuuteen. Teos käsitteleekin nyt puhetta kuoleman edessä konkreettisina teloituslavapuheina tai kertomuksina rikollisten kauhutöistä, joita tuomio tarvitsi perustellakseen oman totuutensa, mutta jotka asettamalla rikollisen sankarin asemaan uhkasivat tuottaa hänelle kunniaa ja yhdistää heidät kansan valtaa vastaan käymään kamppailuun. Uuden rikoskirjallisuuden muodostama rikoksen kaunokirjallistaminen taas esitetään rikosten mielikuvan siirtämisenä pois kansan kamppailusta toiseen yhteiskuntaluokkaan, salapoliisin ja juonikkaan rikollisen älylliseen kamppailuun. "Kansalta ryövättiin sen rikosten vanha pöyhkeys, suurista murhista oli tullut viisaiden hiljaista leikkiä."186 Myös suhde kirjailijoihin muuttuu, ja Foucault ilmoittaa nyt kyllästyneensä "seksin kersantti" Sadeen, joka "muotoili kurinpidolliselle yhteiskunnalle ominaisen erotiikan". ${ }^{187}$ Sade ei olekaan enää kielen raa'an voiman kumouksellisuutta juhlivan modernin kirjallisuuden vaan kätkettyä halua etsivien, modernin ruumiisiin kohdistuvien väkivallan kuriutopioiden edeltäjä.

Mutta kun Foucault vuorostaan kääntyy 70-luvun militantista taistelujen korostamisesta hallitsemisen kokemuksen pohdintaan ja lopulta eettisen itsen hallinnan kysymykseen, palaavat estetiikka ja esteettinen kumous taas hänen pohdintojensa keskiöön. Kyse ei ole tosin enää kielen ja käsityskyvyn ulkorajoja kohti suuntaavasta ylevän estetiikasta vaan annetun subjektin kyseenalaistavasta, itsesuhdetta muokkaavasta kauniin muodon estetiikasta. Eettinen itsensä työstäminen asettuu olemassaolon taidon ja taiteen (arts d'existence) kysymyksenä, jolla Foucault tarkoittaa käytäntöjä, joilla ihmiset pyrkivät "muuttumaan ja muokkaamaan itseään ainutkertaisessa olemisessaan ja tekemään elämästään teoksen, jolla olisi tiettyä esteettistä arvoa ja joka vastaisi tiettyjä tyylikriteereitä". ${ }^{188}$ Tämän eettisen substanssin muokkauksen perustekstin Foucault löytää nyt sokraattisesta Alkibiades-dialogista, jolle myöhäisantiikissa annettiin lisänimi: ih-

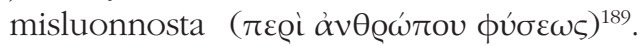
Tuo eettinen itsensä työstäminen yhtyy kulttuurikriittiseen totuudenpuhumiseen varsinkin antiikin kyynikoiden ajattelussa, jonka modernina ilmaisuna Foucault näkee modernin taiteen ja taiteilijan elämän asettumisen suhteeseen taiteen totuuteen. Sen elämän estetiikassa, jota edustavat niin Manet, Francis Bacon, Baudelaire, Samuel Beckett kuin Burroughskin, antiplatonisesti "taide on elementaarisen esiin tunkeutumisen sija, olemassaolon paljaaksi saattaminen" ${ }^{190}$ Paul Veynen Collège de Franceen modernista filosofiasta luennoimaan kutsuma Jürgen Habermas oli kritisoinut ranskalaista ajattelua valistuksen ja modernin projektin nietzscheläisestä hylkäämisestä. Itse hän pyrki Hegelin historiallisen hengen perinnön lunastamiseen intersubjektiivisen ihmisyyden etsimässä teleologisessa totuudessa. ${ }^{191} \mathrm{Fou}-$ cault ehdotti Habermasille yhteistä seminaa- 
ria valistuksesta ja asettui viimeisissä valitusesseissään valistuksen ja modernin puolelle kaikkia humanistis-ideologisia hengen sovituksia vastaan. Valistuksessa oli kyse tiedon jatkuvasta itsekritiikistä, ei sen humanistisesta lunastuksesta. Vastaavasti modernin kokemus oli juuri Baudelairen runoilema kokemus vailla sovitusta olevasta jatkuvasti itsensä kyseenalaistavasta esteettisestä kokemuksesta. Se löysi maalauksellisen ilmaisunsa Baudelairen "modernin elämän maalariksi" nimeämästä Constantin Guysta, tuosta " ei-minää kyltymättömästi havittelevasta minästä, joka muuntaa tuon ei-minän joka hetki kuviksi, ilmaisee sen kuvina, jotka ovat elävämpiä kuin elämä itse, levoton ja alati pakeneva elämä”. ${ }^{192}$ Guy on esimerkki maalarista, joka "viipyilee kaikkialla, missä päivänvalo vielä välkähtelee, runous kaikuu, elämä kuhisee, musiikki värähtelee [...] missä aurinko vielä valaisee turmeltuneen eläimen ohikiitäviä iloja”. ${ }^{193}$ Mutta vastakohtana noita hetkiä etäisyyden päästä muistiinsa tallentavalle flanöörille, kyseessä on "ihmisten suuren autiomaan halki" vaeltava, ikuista ohimenevästä tavoitteleva "kiihkeä mielikuvitus". ${ }^{194}$ Tässä mielikuvituksessa "nykyisyyden korkea arvo on erottamaton kiihkeästä kuvittelusta, kyvystä kuvitella se toisin kuin se on ja sen muuntamisesta ei sitä tuhoamalla vaan kahmaisemalla sen sellaisenaan". ${ }^{195}$ Kuten Baudelairen moderni maalari, tuo mielikuvitus ei uneksi antiikin toogista vaan näyttää mustan lievetakin aikansa välttämättömänä asuna samalla tuoden esille siinä ilmenevän tasa-arvon poliittisen kauneuden ja julkisen sielun hiljaisen kauneuden. Jumalan tai ihmisen ohikiitävä kuolema. Baudelairen sanoin: "Me kaikki juhlimme joitakin hautajaisia."196

\section{HÄMÄHÄKKIMIEHEN PALUU}

Nämä kutovat verkkojaan niin kauan hänen ympärilleen, että hänestä itsestään, heidän liikkeittensä hypnotiseeraamana tuli hämähäkki... Nyt hän vuorostaan kehräsi maailman itsestään - sub specie Spinoza. (Friedrich Nietzsche)

Keväällä 1966 Suomessa kärsittiin ennen- näkemättömistä suurtulvista, mutta vuoden kulttuuripoliittista kohua eivät synnyttäneet niinkään ihmisen olemassaolon kyseenalaistava strukturalististen merkkien tulva vaan juopuneen romaanihenkilö Hiltusen karkeakielinen saarna Jeesuksen seikkailuista tiineen aasintamman kanssa, joka johti tuon fiktiivisen sankarin luoneen tekijän ja tämän kustantajan jumalanpilkkasyytteeseen. Vähemmälle huomiolle jäi huhtikuussa tapahtunut Suomen kumitehdas Oy:n ja Suomen Kaapelitehdas Oy:n yhdistyminen Oy Nokia Ab:ksi. Lähes puoli vuosisataa myöhemmin Foucault on yksi eniten siteeratuista ihmistieteiden ajattelijoista ja jokainen suomalainen tuntee Oy Nokia AB:n globaalin "connecting people" -iskulauseen. "Kuka otti Michelangelon paikan", ${ }^{197}$ kysyi Malraux kuuluisassa "ihmisen kuolema" -puheessaan, mutta Nokiaa ei kuitenkaan ole syytetty jumalanpilkasta, vaikka sen "yhdistyvät kädet" -tunnus kopioi Michelangelon ihmisen luomista kuvaavaa kattofreskoa ja asettaa itsensä tuohon kristillisyydessä Kristukselle kuuluneeseen ihmisen ja jumalan välityksen välitilaan. ${ }^{198}$ Telekommunikaatiofirman symboli muistuttaakin meitä päivittäin televerkkojen asemasta ihmisten uuden kommunikaatiotilan synnyttäjänä. Ne ovat informaatioyhteiskunnassa korvanneet pyhälle ehtoolliselle pirteistään lähtevien kansalaisten yhteisyyden ruumiillistuneen sanan jakajana ja verkostotaloudessa rientävien väkijoukkojen lörpöttelyn mahdollistavana aineettoman aineellisuuden rakenteena. Myös kirkko, tämä Jumalan entinen maallinen huone, jonka kulttuuripoliittisen vallan joutsenlauluksi vuoden 1966 Salama-sota on usein nähty, on kokemassa taas uuden tietoverkkojen kautta tapahtuvan lopullisen joukkopaon, kun se kaikista verkostointistrategioistaan huolimatta on ollut kykenemätön vastaamaan jo vuoden 1968 aloittamaan uuteen sukupuolisuuden politiikkaan. Samalla tekijän oikeuksista ja velvollisuuksista puhutaan taas kenties enemmän kuin koskaan, mutta juuri suhteessa verkoissa vapaasti levitettäviin teoksiin tai siellä rajattomasti leviävään ja usein väkivaltaisia ja affektiivisia ilmauk- 
sia saavaan loputtomaan anonyymiin muminaan. Ranskalaiset sosiologit kirjoittavatkin nyt vuoden 1968 kapitalismin kriisin ja sen taiteellisen ja yhteiskunnallisen kritiikin läpikäyneestä ja sisäistäneestä uutta verkostotaloutta ohjaavasta kapitalismin uudesta hengestä. ${ }^{199}$

Kommentoidessaan 60-luvulla uuden romaanin avantgarden synnyttämää uutta kirjallisuutta Foucault totesi, että kirjallisuus, joka oli "lakannut olemasta retoriikkana ja hävinnyt kirjastona" oli nyt "muodostamassa itseään verkostona". ${ }^{200}$ Kenties Foucault olikin lopulta parempi profeetta kuin historioitsija. Sillä aikoinaan juuri SA:n kaikkein ylitseampuvimpana lausumana pidetty toteamus ihmisen mahdollisesta katoamisesta tiedonjäsennyksen perustasta on nykyään osoittautunut täysin todeksi. Ihmisen kasvot rantahiekalla ovat peittyneet ihmisten kalastelijoiden lukemattomiin verkkoihin uudessa verkostojen "maailmassa ilman ulkopuolta". ${ }^{201}$ Verkostosta on tullut empiiristä tietoamme ja itse olemassaolomme jäsentävä uusi klassisen ajan taulukko. Me emme enää luokittele, me verkostoidumme. Meillä on verkostohistoriaa, verkostososiologiaa, verkostotaloutta, verkostopolitiikkaa ja vieläpä vietämme suurimman osan työ ja vapaa-ajastamme kasvottomissa tietoverkoissa, jotka muistuttavat sitä rihmaston mallia, jonka ranskalaisfilosofit Gilles Deleuze ja Félix Guattari halusivat asettaa strukturalismin jälkiaallossa puumallisen evoluutioajattelun tilalle. ${ }^{202}$ Humanistitkin eksyvät enää harvoin kirjastoihin ja yrittävät sen sijaan jäsentää tietämystään globaalin tietoverkoston rajattomassa informaation tulvassa. Ja vaikka nykyään monet etsivät noista verkoista myös omiin ihmissuhdeverkostoihinsa sitä ihan omaa ihmistään, tuskin kukaan todella uskoo verkkojen kertovan sen enempää totuutta jumalasta kuin lunastavan ihmisen olemusta. Mutta samalla verkostoituminen ei ole vain uusi tiedon tekniikka, vaan aikamme tiedon ja totuuden ilmenemisen ehto, kielenkäytön, tuotannon levittämisen ja jopa elämän järjestämisen käskysana. Puhumattakaan siitä, että me jäsennämme ja muok- kaamme pääasiassa juuri verkostojen kautta eettistä olemassaolomme tapaa suhteessa itseemme ja muihin.

Gilles Deleuze kritisoi aikanaan SA:ta siitä, että se antoi etusijan kielen kokemukselle, joka kirjallisuuden muodossa saattoi uudestaan löytää hajaantuneen kielen olemisen voimat. Deleuze mukaan samalla tavalla organismin tilasta hajaantunut elämä saatettiin koodata uudelleen geneettisen koodin käsitteessä ja työn käsitteestä vapautunut tuotanto taas informaatioteknologiassa. Deleuzen mukaan kysymys "yli-ihmisestä" olikin asettava suhteeseen näiden uusien voimien analyysin kanssa, jos emme halua vajota analyysissämme sarjakuvan tasolle. ${ }^{203}$ Mutta eivätkö juuri sarjakuvien luomat populaarikulttuurin kuvitteelliset Herakleshahmot, nämä lapsekkaan mielikuvituksen yli-ihmiset, näytä toimivan aikansa kulttuuristen muutosten indekseinä. Zarathustran ensimmäisessä englanninkielisessä käännöksessä Thomas Common käänsi Nietzschen übermensch-käsitteen sanalla superman. Terästeollisuuden ja teräksisen Stalinin kanssa voimiaan koettelevan kylmän sodan ajan amerikkalaisen sarjakuvan Supermanhahmo taas käännettiin suomeksi oivallisesti Teräsmieheksi. Kylmän sodan loppu taas nosti esille aikaisemman ironisen lepakkomiehen nyt synkeän postmodernin ja goottilaisen Gotham Cityn miljardöörihahmona, jonka sielunmaisema kuvasti hegeliläistä historian loppua. Nykyään nelivuotias poikani ei tunne Teräs- tai Lepakkomiestä, mutta on hyvin ylpeä Hämähäkkimies-kalsareistaan, paidastaan ja sukistaan. Tuo ihmisen ja hämähäkin voimat risteyttävä hahmo luotiin 60-luvulla samaan aikaan kun strukturalismi halusi asettaa Spinozan hämähäkinverkot hegeliläistä hengen teologiaa vastaan. Varsinaisen maailmanvalloituksen Hämähäkkimies teki kuitenkin vasta verkostoyhteiskuntien suosikkisupersankarina ja telekommunikaatiofirmojen maskottina. Ahdistunut, ujo ja kiusattu pätkätyöläinen Peter Parker muuttuu tuossa yli-ihmisfantasiassa verkostoja itsestään sylkeväksi ja niissä ketterästi liikkuvaksi ihmishämähäkiksi. Foucault oli 
oikeammassa kuin kenties itse koskaan osasi ajatella. Ihminen oli 1800-luvun kek- sintö. Aikamme on korvannut sen verkoissa kyyhöttävillä hämähäkeillä.

\section{vi i t t e e t}

1. Hegel [n.1796] 1979, 234.

2. Hegel [n.1796] 1979, 235.

3. Hegel [n.1796] 1979, 235.

4. Hegel [1835] 1968, 25.

5. Näyttelystä otetussa kuuluisassa kuvassa John Heartfield ja George Grosz pitelevät julistetta, jossa lukee Die Kunst ist tot: Es lebe die neue Maschinenkunst TATLINS. Lausuma tulee Konstantin Umanskyltä, joka oli teoksessaan uudesta venäläisestä taiteesta kirjoittanut avantgardisti Tatlinin kehittäneen Picasson ja Braquen kokeilujen perustalta konetaidetta, jossa mikään aine ei ole liian vähäpätöistä taiteelle, paperi, metalli, naulat jne. "Taide on kuollut - kauan eläköön taide, Konetaide." (Hays 1992, 177.)

6. Surrealismi-tutkimuksiaan jatkaneessa vaikutusvaltaisessa teoriassaan avantgardesta Peter Bürger korostikin juuri avantgarden pyrkimystä kumota sen omana historiallisena ehtona toiminut autonomisen ja erillisen taiteen asettanut moderni estetismi ja liittää taide takaisin elämän käytäntöön. "Avantgarde-liikkeissä taiteen muodostama yhteiskunnallinen alajärjestelmä saapuu itsekritiikin vaiheeseen. Dada, Euroopan avantgardesta kaikkein radikaalein, ei enää kritisoi sitä edeltäneitä koulukuntia vaan taidetta instituutiona ja sen saamaa muotoa porvarillisessa yhteiskunnassa. (Bürger [1974], 1999, 22.) Bürger pyrkikin tämän pohjalta erottamaan taiteen modernismin ja avantgarden, edellisen pyrkiessä taiteen muodon kokeiluun, jälkimmäisen sen yhteiskunnallisen aseman kritiikkiin ja kumoamisen kautta säilyttävään aufhebungiin. Vaikka Bürgerin huomautus avantgarden historiallisesta asemasta juuri historiallisen taide-instituution kritiikkinä on paikallaan suhteessa modernismin ja avantgarden yhdistämiseen puhtaina esteettisinä liikkeinä, on erottelu myös ongelmallinen ja seurausta Bürgerin omasta historiallis-hermeneuttisen kritiikin dialektiikasta.

7. Surrealismin Kristus ja paavi olivat itse asiassa antibretonilaisen Un Cadavre-pamfletin (15.1.1930) haukkumanimiä Bretonille. Pamfletissa oli kuva Bretonista orjantappurakruunua kantavana Kristuksena ja sen vieressä otsikko Papologie d'André Breton. Ks. viite 10.
8. Nancy [1966] 2007.

9. Pamphlet [1924] 1980.

10. Il ne faut plus que mort cet homme fasse de la poussière. (Breton [1924], 1992, 128.)

11. Pamfletti, joka lainasi Bretonin omia aikaisempia Anatole Francesta käyttämiä sanoja oli ensimmäisen pamfletin ironinen toisto. Se syntyi surrealisteista karkotetun Robert Desnosin aloitteesta, mutta yhdistettiin ennen kaikkea Batailleen, joka oli kerännyt oman Documents-lehtensä ympärille ex-surrealisteja. Myöhemmin Bataille tosin harmitteli koko polemiikkia. (Bataille [1954] 2004.)

12. Bataille [1929]1970, 218.

13. "Niissä oireissa, jotka saattavat porvariston, aateliston ja kehnot taantumusprofeetat hämmingin valtaan, me tunnistamme vanhan hyvän ystävämme Robin Goodfellow'n, vanhan maamyyrän (Maulwurf), joka osaa kaivaa niin nopeasti maan alla, tuon mainion miinoittajan, vallankumouksen." (Marx [1856] 1963, 4.)

14. Bataille [1930], 1970.

15. Bataille 1937, 20.

16. Bataille 1937, 20.

17. Enkeli ja hirviö on teema, jonka alla Bataillen elämänkerturi Michel Surya käsittelee näiden kahden miehen intellektuaalista viharakkaus-suhdetta ja kiistaa surrealistisesta liikkeestä, johon Bataille ei koskaan varsinaisesti kuulunut, mutta joka omin sanoin liikkeen vanhana sisäisenä vihollisena näki sen pettävän siihen asetetut mahdollisuudet. (Surya 2002.)

18. J.-P. Sartre [1948], 1967, 164.

19. J.-P. Sartre [1948], 1967, 164.

20. Foucault [1966], 1994/43, 554.

21. Foucault [1966], 1994/43, 554.

22. Foucault [1966], 1994/43, 555.

23. Usein lainattu Bretonin "infracassable noyau de nuit" on tämän esipuheesta saksalaisen varhaisromantiikon Achim von Arnimin romaaniin. "De nos jours, le monde sexuel, en dépit des sondages entre tous mémorables que, dans l'époque moderne, y auront opérés Sade et Freud, n'a pas, que je sache, cessé d'opposer à notre volonté de pénétration de l'univers son infracassable noyau de nuit." (Breton [1933] 1934, 188.) 
24. Foucault [1954], 1994/1, 118.

25. Foucault [1966], 1994/43, 556.

26. Foucault [1966], 1994/43, 556.

27. Foucault [1966], 1994/43, 556.

28. "Me vaadimme politiikan ja taiteen ykseyttä, sisällön ja muodon ykseyttä, vallankumouksellisen poliittisen sisällön ja mahdollisimman täydellisen taiteellisen muodon ykseyttä. Taiteelliselta laadultaan puutteellisilla taideteoksilla ei ole tehoa, olivatpa ne sitten poliittisesti miten edistyksellisiä tahansa. Sen vuoksi me vastustammekin sekä poliittiselta näkökannaltaan virheellisiä taideteoksia että taipumusta 'juliste- ja iskulausetyyliin', joka on poliittiselta näkökannaltaan oikeaa, mutta taiteelliselta voimallaan puutteellista. Kirjallisuuden ja taiteen kysymyksissä meidän on käytävä taistelua kahdella rintamalla." (Tsetung [1942] 1965, 90.) Maon puheesta kirjallisuuden ja taiteen kysymyksiä käsittelevässä Jenanin kokouksessa 1942. Liitetty pienen punaiseen kirjaan 1964.

29. Kansainvälisten situationistien jäsenien ja Strasbourgin opiskelijoiden nimissä julkaistun pamfletin koko nimi oli: Opiskelijaelämän surkeudesta ymmärrettynä sen taloudellisista, polittista, psykologisista ja erityisesti intellektuaalisista näkökulmista ja joitakin keinoja sen parantamiseen. (U.N.E.F. [1966] 2010.)

30. Osansa saivat myös opiskelijoita elämänsä ongelmista vieraannuttavat "Mitkä ovat kirjallisuuden mahdollisuudet?" -spektaakkeliseminaarit sekä täydellisen esteettisen kumouksen fragmentaarisuutta juhliva aristokraattis-poliittinen provotariaatti. (U.N.E.F. [1966] 2010.)

31. U.N.E.F. [1966] 2010.

32. Uuden aallon tähden Jean-Pierre Léaudin esittämä solun näyttelijäjäsenen etunimi viittaa surrealisti-sanan kehittäneeseen Guillaume Apollinaireen ja sukunimi Goethen klassisen bildung-romaanin sankarin sukunimeen.

33. Tosin kapitalistin, Kosygenin ja De Gaullen jälkeen teos on numeroitu vasta viholliseksi nro 122.

34. Godard [1967] 1968-9, 25-6. Godard myönsi lukeneensa Foucault'n kohukirjasta ainoastaan kauniina pitämänsä Velasquez-kuvauksen, mutta valmistellessaan elokuvansa kuvauspaikkoja yliopistolla oli alkanut pitää sitä kuulopuheiden kautta epäilyttävänä.

35. L'art est mort. Godard n'y pourra rien. (Besançon [1968] 2007, 42.)

36. Foucault [1978], 1994/281, 49.
37. Kanapa 1947.

38. J. P. Sartre [1946], 1976.

39. Sartea vastaan suunnatusta hyökkäyksestä ja marxismi-eksistentialismi keskustelusta ks. mm. Poster 1975.

40. Stalin [1938], 2010.

41. Lefebvre [1940], 2009, 150.

42. Lefebvre [1940], 2009, 150.

43. Marx [1844], 1968, 583.

44. Marx [1844], 1968, 536.

45. Hyppolite [1955], 1969, vii.

46. Hyppolite [1955], 1969, 128.

47. Veyne 2007; Macey 1993, 39.

48. Foucault [1978], 1994/281, 50.

49. Kirjailija Louis Aragon perusti André Bretonin ja Philippe Soupaultin kanssa Littérature -aikakausilehden, joka toimi surrealististen kirjallisten kokeilujen lähtökohtana. Surrealismin alusta suomeksi ks. mm. Kaitaro 2001.

50. Aragon [1953], 1999.

51. Merleau-Ponty [1947], 2001, 176.

52. Merleau-Ponty [1947], 2001, 153.

53. Marx [1843], 1968, 389.

54. Merleau-Ponty [1947], 2001, 156.

55. Merleau-Ponty [1947], 2001.

56. Hruštšov [1956] 2010.

57. Merleau-Ponty [1956], 1964, 304.

58. Merleau-Ponty [1955], 1973.

59. Merleau-Ponty [1960], 1964.

60. Merleau-Ponty [1960], 1964, 21,33.

61. Althusser [1964], 1986, 227.

62. Fromm ilmoitti ettei essee mielenkiintoisuudestaan huolimatta sovi teokseen. Althusser julkaisi sen 1964 sekä Italiassa että Ranskassa ja se kuuluu myös 1965 julkaistuun Pour Marx -kokoelmaan, jonka tämä lähetti Foucault'lle juuri ennen SA:n ilmestymistä. Ks. (Althusser [1967] 2003.)

63. Althusser [1964], 1986, 229.

64. Althusser [1964], 1986, 234.

65. Althusser viittaa heidän luentansa selkeään ja salattuun velkaan tiedon (savoir) teosten mestarien luennoille: Cavaillèsille ja Bachelardille ja nyt Canguilhemille ja Foucault'lle. (Althusser [1965], 1973, 13 nootti1.) Althusser vietti lähes koko elämänsä École normale supérieuressä, jossa hän oli opiskellut ja toimi sitten kaimaanina, jonka tarkoitus oli valmistella opiskelijoita lopputyöhönsä.

66. Lainattu teoks. Althusser [1967] 2003, 299). Garaudyn aatteellinen matka kulki ankarasta stalinistista humanismin kautta katolilaisuuteen, jonka tähden hän joutui eroamaan puolueesta. Sittemmin hän kääntyi islamin uskoon ja hänet tunnetaan nykyään juutalaisten 
joukkotuhon kieltäjänä hänen kirjoitettuaan teoksen Israelilaisen politiikan perustavista myyteistä.

67. "Marxismi on aikamme humanismia, koska se perustuu ankaraan tieteelliseen maailmankäsitykseen, mutta se ei erota yritystään ymmärtää maailmaa päätöksestään muuttaa sitä kaikkien ihmisten eduksi." Lainattu teoksesta Althusser [1967] 2003, 299.

68. Garaudy, [1967], 2009, 299. Garaudy oli tullut valituksi Clermont-Ferrandin yliopistoon Gilles Deleuzen tilalle puolueen avulla. Foucault inhosi Garaudya ja antihumanistisesti työpaikkakiusasi tätä mm. syyttäen miestä virkavirheestä tämän vaadittua opiskelijoita kääntämään Marcus Aureliusta latinasta.

69. Viittaus on jesuiitta Pierre Teilhard de Chardiniin, joka pyrki yhdistämään kristillistä ja marxilaista humanismia ja johon vuorostaan Garaudy viittasi positiivisesti.

70. ”Althusserin ja minun välillä on selkeä ero: hän käyttää epistemologisen katkoksen termiä Marxin suhteen, minä taas väitän päinvastaisesti ettei Marx edusta epistemologista katkosta." (Foucault [1966], 1994/48, 587.)

71. Foucault [1966], 1994/48, 587.

72. "Tämä historian epistemologinen muutos ei ole vielä päässyt loppuun asti. Se ei kuitenkaan ole aivan tuore, sillä sen ensimmäinen vaihe voidaan epäilemättä jäljittää Marxiin.” (Foucault, 2005, 23.)

73. Althusser [1964], 1986, 258.

74. Foucault (1966), 1994/37, 516.

75. "Die hochste hur, die der Teuffel hat." (Luther [1546] 1914, 216.)

76. Foucault [1967], 1994/50, 616.

77. "Tarkemmin ajateltuna, sanoisin, että 'veltto humanismi' on puhtaasti redundantti muotoilu ja 'humanismi' implikoi kaikella tapaa 'veltoutta'." (Foucault [1967], 1994/50, 615.)

78. Foucault (1968), 1994/55, 668.

79. Foucault [1983], 1994/339, 573.

80. Foucault totesi hirviömäisen antihumanisminsa kenties saaneen alkunsa juuri Ruotsissa. (Foucault [1968], 1994/54, 615.)

81. Foucault [1967],1994/50, 617.

82. Bourg 2007, 3.

83. Keskustelu Ranskan filosofisessa seurassa Foucault'n 22.2.1969 pitämän "Mitä on tekijä?" esitelmän jälkeen. (Foucault [1968], 1994/69, 820.)

84. Myös yliopistoilla vuosi 1968 johti lopulta strukturalismin vahventumiseen.

85. Foucault [1978], 1994/281, 64.

86. Foucault [1974], 1994/136, 524.
87. Foucault [1978], 1994/281, 82.

88. G. Lukács, Die Theorie des Romans 1920, 84.

89. G. Lukács [1923], 1967.

90. Lukács 1934. Kansallissosialistit järjestivät "Entartete Kunst" -näyttelynsä vuonna 1937 ja alkoivat tuhota modernia avantgardetaidetta, ekspressionismi mukaan lukien.

91. G. Lukács [1936], 8.

92. Mt.

93. G. Lukács [1955], 1979, 400.

94. Bataille 1937, 5.

95. Bataille 1955, 64. Bataillen mukaan Manet'n kangas, joka "oli vastakkaista kaikelle mitä siihen aikaan maalaukselta odotettiin", edusti modernin ajan esteettistä alkua ja aloitti samalla nuo torjunnan ja halveksunnan "vihan päivät", joiden merkeissä tästä lähin yleisö tuli vastaanottamaan jokaista taiteen nuorentamisen uutta yritystä (Bataille 1955, 17). Bataillen Manet-luennan yhteydestä tämän ajatteluun taiteesta mahdottoman suvereenisuuden ilmentymänä Arppe 2003.

96. Foucault ehti tehdä teoksesta kustannussopimuksen Minuit'n kanssa, mutta ei koskaan julkaissut teosta. Jäljellä on ainoastaan Foucault'n Manet'sta vuonna 1971 Tunisiassa pitämä esitelmä. La peinture de Manet. Conférence à Tunis, le 20 Mai 1971.

97. Foucault [1969], 2005, 251.

98. Foucault [1971], 2009, 66.

99. Bataille, Manet 1955, 58.

100.Malraux [1953], 1978, 639. Alunperin kolmiosainen La Psychologie de l'Art, 1947-1949 julkaistiin uudestaan 1951 yhdistettynä teoksena Les Voix $d u$ silence. Itselläni on ollut käsillä vain teoksen englanninkielinen käännös vuodelta 1953.

101.Malraux [1953], 1978, 635.

102.Malraux [1953], 1978, 642.

103.Merleau-Ponty [1960], 1964, 62.

104.Merleau-Ponty [1960], 1964, 62.

105.Merleau-Ponty [1960], 1964, 82.

106.Merleau-Ponty [1960], 1964, 63).

107.Foucault [1967/1984], 1994/360, 759.

108. Foucault [1954], 1994/1, 100.

109. Foucault [1954], 1994/1, 119.

110. Foucault [1954], 1994/1, 119.

111.Foucault [1964/7], 1994/20., 297.

112.Foucault [1964/7], 1994/20, 101.

113.Foucault [1968], 1994, 651.

114. Maigritte maalasi aiheesta monta versiota, joista tunnetuin, La trahison des images esitti piipun kuvaa ja sen alle kirjoitettua "tämä ei ole piippu" -tekstiä. Viimeinen vuoden1966 Les deux mystères -versio taas esitti tuon esi- 
tyksen liitutauluesityksenä huoneessa, jossa leijui piipun kuva.

115.Foucault [1964], 1994, 326.

116.Foucault [1975] 1994/163, 812.

117.Foucault [1966], 1994/39, 544.

118. Foucault liitti jo vuotta aikaisemmin $L e$ Mercure de France -kirjallisuuslehdessä julkaistun ja omasta mielestään kirjan muuhun analyysiin verrattuna liian runollisen tekstin teoksen alkuun vasta kustannustoimittajansa Pierre Noran vaatimuksesta.

119.Foucault [1961] 1994/4, 159.

120.Pico 1496, \$20, 118.

121.Hegel [1835], 1968, 194. Historian filosofiassaan Hegel taas puhui roomalaisesta elämän proosasta ja Etruskien taiteen hengen proosasta.

122."Hegel sanoi Rooman valtion olevan maailman proosa. Nimeän kirjani johdannoksi maailman proosaan. Tuossa teoksessa käsittelen proosan kategoriaa kirjallisuuden rajojen ulkopuolella antaakseni sille sosiologisen merkityksen." (Merlau-Ponty [1962] 1964b.) Foucault suunnitteli Maailman proosasta mahdollista nimeä koko "merkkien kirjalleen", kunnes kuuli, että Merleau-Pontyn jäämistöstä oli löydetty tuon kirjan käsikirjoitus. Claude Lefort toimitti keskeneräisen käsikirjoituksen 1969 kirjaksi. (Merleau-Ponty 1969.)

123.Derrida [1963] 1967.

124.Derrida 1965; 1966. Näiden artikkeleiden kehitellyt versiot muodostivat ensimmäisen osan Derridan vuonna 1967 julkaisemasta Grammatologia-teoksesta.

125.Curtius oli todennut, että "kirjallisuustiede on käsitellyt tuskin lainkaan kirjoitusta (kirjaimien käyttöä) ja kirjaa”, vaikka näillä on ollut keskeinen osa latinalaisen kirjallisuuden kielikuvissa. Curtius näki Platonin kirjoituksen väheksymisen ominaisena kreikkalaiselle kulttuurille, mutta korosti kuitenkin tämän asetelman muutosta jo hellenistisellä ajalla ja lähes päinvastaiseksi kääntymistä kristillisessä ja renessanssikulttuurissa. Curtiuksen mukaan kirja menetti auktoriteettinsa vasta valistuksen aikana. (Curtius [1953] 1990, 302-347.) Curtiuksen kirjallisuushistoriallisella teesillä oli keskeinen vaikutus Derridan sen pohjalta tekemään radikaalimpaan tulkintaan kirjoituksen väheksymisestä.

126.Derrida 1967, 27.

127.Foucault 1966, 53.

128. Foucault 1966, 56.

129.Foucault 1966, 56.

130.Foucault 1966, 52.
131. Quintiliani Inst, 3,3,1.

132. Curam ergo verborum rerum volo esse sollicitudinem. (Quintiliani Inst, 8 pr.20.)

133.Swift [1726], 1953, 236.

134.Foucault [1971 ] 1994/89, 171.

135.Hyppolite [1952] 1997, 40.

136.Vaikka hullu ja runoilija asettuvat yhdessä tuon tiedon rakenteen laidoille, heillä on vastakkainen tehtävä. Hullulla kyse on homosemanttisesta merkkien sekoittamisesta, runoilijalle allegorisesta representatiivisen kielen takaisen samankaltaisuuden löytämisestä.

137.Zola 1898.

138. Barthes 1963.

139. Barthes [1966], 2004. Sosiologi Bourdieu vuorostaan analysoi heti vuonna 1966 PicardBarthes tapausta Racinen yhteisen arvon olettavana intellektuaalisena kenttätaisteluna ja sittemmin erilaisina strategisina valintoina suhteessa yliopistokulttuurin rakenteellisiin muutoksiin (Bourdieu 1984, 151-167). Niilo Kauppi on vuorostaan analysoinut "bourdieulaisesti" uuden romaanin ja Tel Quelin ilmaiseman uuden kirjallisuusintellektuellin nousua Sartren symbolisesti tapetun ruumiin paikalle. (Kauppi 1996.)

140.Robbe-Grillet [1963] 1996, 57.

141.Robbe-Grillet [1963] 1996, 19.

142.Robbe-Grillet [1963] 1996, 41.

143.J.-P. Sartre [1948], 1967, 207.

144.J.-P. Sartre [1948], 1967, 251.

145.J.-P. Sartre [1948], 1967, 240.

146.J.-P. Sartre [1948], 1967, 245.

147.J.-P. Sartre [1948], 1967, 21.

148.J.-P. Sartre [1948], 1967, 237.

149.J.-P. Sartre [1948], 1967, 237.

150.J.-P. Sartre [1948], 1967, 21.

151.Mallarmén keskeisestä asemasta ranskalaisessa kirjallisuusdebatissa ks. Hollier \& Mehlman 1999, osa kolme, "The Central case of Mallarmé".

152.Foucault [1964], 1994/28, 429.

153. Foucault [1964], 1994/28.

154.J.-P. Sartre [1953], 1999, 190.

155.J.-P. Sartre [1943], 1947, 171.

156.Foucault [1963], 1994/13, 236.

157. Blanchot [1955], 2003, 187.

158.Foucault [1966], 1994/38.

159. Foucault [1966], 1994/38, 520.

160.Foucault [1970], 1994/82, 124.

161.Foucault [1970], 1994/82, 124.

162.Foucault [1970], 1994/82, 123. Susanna Lindberg on käyttänyt hienossa L'espace littérairen käännöksessään termiä "kirjallinen avaruus", 
joka kenties voi kuulostaa sanatarkemman "kirjallisen tilan" sijaan hieman kosmiselta, mutta toisaalta tuo esiin juuri Blanchot'n ajatuksen kirjallisuuden tilasta omana kosmoksenaan tuota kosmosta asuttavine kirjallisine pyhimyksineen.

163.Veyne, René Char en ses poémes, 1990.

164.Foucault [1978], 1994/281, 43.

165.Roudinesco [1993], 1999.

166.Aragon Louis \& Breton André [1928], 1948.

167.Foucault [1964], 1994/25.

168.Scardanelli oli nimi, jolla Hörderlin signeerasi hulluutensa aikana runonsa.

169. Foucault [1963], 1987, 166.

170.Foucault [1963], 1987, 165.

171." Développez votre étrangeté légitime." (Foucault [1961] 1994/4, 167; Char [1948] 1962, 71.)

172." L'histoire des hommes est la longue succession des synonymes d'un même vocable. $Y$ contredire est un devoir." Foucault'n viimeisten kirjojen ainoa takakansiteksti. Paul Veyne on kuitenkin väittänyt, että itse asiassa runoilija ja filosofi käsittivät tuon lausuman lähes toisilleen vastakkaisella tavalla. Char ymmärsi tällä, ettei katastrofiinsa pienissä eroissaan palautuvan ihmiskunnan seikkailu ollut runoutta. (Veyne 1990, 499.)

173.Foucault väittää nyt, että hän ainoastaan käsitteli kirjallisuutta sivunmennen $\mathrm{Hul}$ luuden historiassa ja SA:ssa antamatta sille mitään keskeistä roolia kirjoitusprosessissa. (Foucault 1988, 307.) Kuitenkin erityisesti Hulluuden historian sittemmin Foucault'n poistama ensimmäinen esipuhe asettaa tuon tutkimuksen itsessään René Charin runouden inspiraation alle.

174. Foucault [1975] 2000, 424.

175. Foucault 2001, 9.

176."Voidaan kuitenkin kysyä, eikö kirjoituksen käsite nykyisessä käytössään muunna tekijän empiirisiä ominaisuuksia transsendentaaliseksi nimettömyydeksi. Tyydytään pyyhkimään pois liian näkyvät osoitukset tekijän empiirisyydestä peluuttamalla vastakkain kaksi tapaa luonnehtia kirjoitusta: kirjallinen ja uskonnollinen. Eikö kirjoitukselle annettu alkuperäinen asema itse asiassa olekin tapa kääntää transsendentaalisille termeille se, että kirjoitus julistetaan pyhäksi teologiassa ja toisaalta luovaksi kirjallisuudentutkimuksessa?" (Foucault 2001, 8.)

177. Barthes 1993, 116.

178. Beckett 1958, 129.

179.Foucault [1970] 1994/82, 115.

180.Foucault [1976], 1994/192, 155.

181.Foucault [1976], 1994/192, 157.

182.Foucault [1976], 1994/192, 145.

183.Foucault [1973], 1994/118, 401.

184.Groupe d'information sur les prisons (GIP), Intolérable n:o 1, Champ libre, 1971. Lainattu Eribon [1991] 1993, 264.

185.Foucault 1988, 308.

186. Foucault [1975] 2000, 72.

187.Foucault [1976], 1994/164, 821.

188. Foucault 1984.

189.Laertios 2002, 121, 3. kirja 59.

190.Foucault 2009, 174.

191. Habermas 1985.

192.C. Baudelaire [1863], 2001, 188.

193.C. Baudelaire [1863], 2001, 189; Foucault [1983], 1994/339, 570.

194.C. Baudelaire [1863], 2001, 190; Foucault [1983], 1994/339.

195.Foucault [1983], 1994/339, 570.

196.C. P. Baudelaire [1946], 1868, 194.

197.Malraux [1949], 1999, 75.

198.Jouko Turkan uutta jumalaa, Nokiaa, pilkkaavaa "connecting people" -näytelmää pidettiin kyllä rivona, mutta ei enää oikeudellisten toimenpiteiden arvoisena.

199.Boltanski Luv \& Chiapello Eve [1999], 2005.

200.Foucault [1963], 1994/7, 279.

201. Verkostojen käsitteestä todellisuutta jäsentävänä kehyksenä ja yhteiskunnan kuvaamisen mallina ks. Eriksson 2009.

202.Deleuze Gilles \& Guattari Félix [1980], 1992.

203.Deleuze 1986, 139.

\section{K I R J A L LIS U U S}

Althusser, Louis [1965], 1973. ”Du Capital à la philosophie de Marx." Teoksessa Lire le Capital 1, tekijä: Louis Althusser \& Étienne Balibar. Paris: Librairie François Maspero.

— [1964], 1986. "Marxisme et Humanisme." Teoksessa Althusser, Pour Marx. Paris: Dé- 
cinquantenaire de l'hysterie (1878-1928)." Teoksessa Nadeau Maurice (toim.), Histoire du surrealisme: Documents surrealistes. Paris: Seuil.

Aragon, Louis [1953], 1999. "On a Portrait of Stalin." Teoksessa Hollier \& Mellis (toim.), Literature Debate. Postwar French Thought. Volume II. New York: The New Press.

Arppe, Tiina 2003. "Georges Bataille ja taiteen mahdoton suvereenisuus." Taide 3: 12-16.

Barthes, Roland [1966], 2004. Criticism and truth. London: Athlone Press.

— 1963. "Les Deux Critiques." MLN, Vol. 78, No. 5: 447-452.

— 1993. "Tekijän kuolema." Teoksessa Barthes Roland, Tekijän kuolema Tekstin syntymä, 109-117. Tampere: Vastapaino.

Bataille, Georges [1954] 2004. "La Publication d' 'Un Cadavre' (15 janvier 1930)." Teoksessa Georges Bataille \& Michel Leiris, Échanges et correspondances. Paris: Gallimard.

— [1930], 1970. "La vieille taupe et le préfixe sur dans les mots surhomme et surréaliste." Teoksessa Oeuvres complètes, Tome II. Paris: Gallimard.

— [1929]1970. "Le Lion châtré." Teoksessa Oeuvres complètes, Tome 1. Paris: Gallimard.

- 1955. Manet. New York: Albert Skira.

- 1937. "Nietzsche et les fascistes." Acéphale 2: 3-13.

- 1937. "Propositions." Acéphale 2: 17-21.

Baudelaire, Charles [1863], 2001. "Modernin elämän maalari." Teoksessa Modernin elämän maalari ja muita kirjoituksia. Jyväskylä: Desura.

— [1946], 1868. "Salon de 1846." Teoksessa CEurres complètes de Charles Baudelaire, Volume II. Curiosités esthétiques. Paris: Michel Lévy frères.

Beckett, Samuel 1958. Nouvelles et Textes pour rien. Paris: Minuit.

Besançon, Julien [1968] 2007. Les murs ont la parole: Journal mural Mai 68. Paris: Tchou.

Blanchot, Maurice [1955], 2003. Kirjallinen avaruus. Vantaa: AI-AI.

Boltanski Luv \& Chiapello Eve [1999], 2005. The New Spirit of Capitalism. London: Verso.

Bourdieu, Pierre 1984. Homo Academicus. Paris: Minuit.

Bourg, Julian 2007. From Revolution to Ethics. May 1968 and Contemporary French Thought. Montreal: McGill-Queen's University Press.

Breton, André [1933] 1934. "Introduction aux
Contes Bizarres d'Achim d'Arnim." Teoksessa Point du Jour. Paris: Gallimard.

— [1924], 1992. "Refus d'inhumer." Teoksessa Oeuvres complètes, tome 2. Paris: Gallimard.

Bürger, Peter [1974], 1999. Theory of the AvantGarde. Minneapolis: University of Minnesota Press.

Char, René [1948] 1962. Fureur et mystére. Paris: Gallimard.

Curtius, Robert Ernst [1953] 1990. European literature and the Latin Middle Ages. Princeton: Princeton University Press.

Deleuze Gilles \& Guattari Félix [1980], 1992. "Rihmasto." Teoksessa Autiomaa: Kirjoituksia vuosilta 1967-1986. Helsinki: Gaudeamus.

Deleuze, Gilles 1986. Foucault. Paris: Minuit.

Derrida, Jacques [1963] 1967. "Cogito et histoire de la folie." Teoksessa L'écriture et la différence. Paris: Seuil.

- 1965; 1966. "De la grammatologie." Critique, No. 223: 16-42; No. 224:23-53.

- 1967. De la Grammatologie. Paris: Minuit.

Eribon, Didier [1991] 1993. Michel Foucault. Tampere: Vastapaino.

Eriksson, Kai 2009. Maailma ilman ulkopuolta. Helsinki: Gaudeamus,.

Foucault, Michel [1968], 1994. "Ceci n'est pas une pipe." Teoksessa Dits et écrits I. Paris: Gallimard.

— [1976], 1994/164. "164 Sade, sergent du sexe." Teoksessa Dits et ècrits II. Paris: Gallimard.

— [1966], 1994/43. "C'était un nageur entre deux mots." Teoksessa Dits et écrits I. Paris: Gallimard.

- [1963], 1987. Death and the Labyrith. The World of Raymond Roussel. London: The Athlone Press.

— [1967/1984], 1994/360. "Des espaces autres." Teoksessa Dits et écrits IV. Paris: Gallimard.

— [1963], 1994/7. "Distance, aspect, origine." Teoksessa Dits et écrits I.. Paris: Gallimard.

— [1968], 1994/54. "En intervju med Michel Foucault. Bonniers Litteräre Magasin, Stockholm, no 3, mars 1968." Teoksessa Dits et écrits I. Paris: Gallimard.

— [1978], 1994/281. "Entretien avec D. Trombadori, Paris 1978." Teoksessa Dits et écrits IV. Paris: Gallimard.

- [1966], 1994/37. "Entretien avec Madeleine Chapsal. La Quinzaine littéraire, $\mathrm{n}^{\circ} 5$, 16.5.1966." Teoksessa Dits et écrits I. Paris: Gallimard.

— [1976], 1994/192. "Entretien avec Michel Foucault." Teoksessa Dits et ecrits III, 140-160. Paris: Gallimard. 
- [1971 ] 1994/89. "Entretien avec Michel Foucault." Teoksessa Dits et écrits II. Paris: Gallimard.

— [1970], 1994/82. "Folie, littérature, société." Teoksessa Dits et écrits II. Paris: Gallimard.

— [1968], 1994/55. "Foucault répond à Sartre." Teoksessa Dits et écrits I. Paris: Galimard.

— [1954], 1994/1. "Introduction, in Binswanger." Teoksessa Dits et écrits I. Paris: Gallimard.

— [1964], 1994/25. "La folie, l'absence d' oeuvre." Teoksessa Dits et écrits I. Paris: Gallimard.

— [1973], 1994/118. "La force de fuir." Teoksessa Dits et écrits II. Paris: Gallimard.

— [1966], 1994/38. "La pensée du dehors." Teoksessa Dits et écrits I. Paris: Gallimard.

— [1964], 1994. "La prose d'Actéon." Teoksessa Dits et écrits I. Paris: Gallimard.

- 2009. Le courage de la vérité. Le gouvernement de soi et des autres II. Paris: Gallimard.

— [1964], 1994/28. "Le Mallarmé de J.-P. Richard." Teoksessa Dits et écrits I. Paris: Gallimard.

- 1966. Les mots et les choses. Paris: Gallimard.

- [1975] 1994/163. "Les réponses du philosophe." Teoksessa Dits et écrits II. Paris: Gallimard.

— [1966], 1994/39. "L'homme est-il mort?" Teoksessa Dits et écrits I. Paris: Gallimard.

—. L'usage de plaisirs. Paris: Gallimard, 1984.

_ [1971], 2009. Manet and the Object of painting. London: Tate Publishing.

— 2001. "Mitä on tekijä?" Nuori Voima 1/2001: $7-14$.

— [1964/7], 1994/20. "Postface à Flaubert." Teoksessa Dits et écrits I. Paris: Gallimard.

— [1963], 1994/13. "Préface à la transgression." Teoksessa Dits et écrits I. Paris: Gallimard.

— [1961] 1994/4. "Préface, Folie et Déraison (1961)." Teoksessa Dits et écrits I. Paris: Gallimard.

— [1974], 1994/136. "Prisons et asiles dans le mécanisme du pouvoir." Teoksessa Dits et écrits I. Paris: Gallimard.

- [1983], 1994/339. "Qu'est-ce que les Lumières ?" Teoksessa Dits et écrits $I V$. Paris: Gallimard.

— [1968], 1994/69. "Qu'est -ce qu'un auteur? (Conférence)." Teoksessa Dits et écrits I. Paris: Gallimard.

— [1967],1994/50. "Qui êtes-vous, professeur Foucault? (Entretien avec P. Caruso.)." Teoksessa Dits et écrits I. Paris: Gallimard.

- [1966], 2010. Sanat ja asiat. Helsinki: Gaudeamus.

— [1966], 1994/48. "Sur les façons d'écrire l'histoire." Teoksessa Dits et écrits I. Paris:
Gallimard.

— [1975] 2000. Tarkkailla ja rangaista. Keuruu: Otava.

— 1988. "The Functions of Literature." Teoksessa Politics, Philosophy, Culture. Interviews and other writings 1977-1984,307-313. London: Routledge.

- [1969], 2005. Tiedon arkeologia. Tampere: Vastapaino.

Godard, Jean-Luc [1967] 1968-9. "Struggle on Two Fronts: A Conversation with Jean-Luc Godard." Film Quarterly, Vol. 22, No. 2: 20-35.

Habermas, Jürgen 1985. Der philosophische Diskurs der Moderne. Zwölf Vorlesungen. Frankfurt am Main: Suhrkamp.

Hays, K. Michael 1992. "Photomontage and Its Audience: El Lissitzky Meets Berlin Dada." Teoksessa Marquardt \& Roman (toim.), The Avant-Garde Frontier: Russia Meets the West, 1910-1930. Gainesville: University Press of Florida.

Hegel, Georg Wilhelm Friedrich [n.1796] 1979. "Das älteste Systemprogramm des deutschen Idealismus." Teoksessa Werke. $B d$ 1.. Franfurt am Main: Suhrkamp.

— [1835] 1968. "Vorlesungen über Ästhetik I." Teoksessa Werke. Bd 13.. Franfurt am Main: Suhrkamp.

Hollier \& Mehlman 1999. Liteary debate. New York: The New Press.

Hruštšov, Nikita [1956] 2010. "О культе Аичности и его послелствиях." ХРОНОС всемирная история в интернете. http://www.hrono.ru/ dokum/doklad20.html (haettu 2010).

Hyppolite, Jean [1955], 1969. Studies on Marx and Hegel. London: Heinmann.

-. The Logic of Existence. Albany: State University of New York Press,, [1952] 1997.

Kaitaro, Timo 2001. Runous, raivo, rakkaus. Johdatus surrealismiin. Helsinki: Gaudeamus.

Kanapa, Jean 1947. L'Existentialisme n'est pas un humanisme. Paris: Éditions sociales.

Kauppi, Niilo 1996. French Intellectual Nobility. New York: State University of New York Press.

Laertios, Diogenes 2002. Merkittävien filosofien elämät ja opit. Helsinki: Summa.

Lefebvre, Henri [1940], 2009. Dialectical Materialism. Minneapolis: University of Minnesota Press.

Lukács, Georg 1920. Die Theorie des Romans. Berlin: Verlegt bei Paul Cassirer.

— [1923], 1967. History and Class Consciousness. Studies in Marxist Dialectics. Cambridge: The 
Mitt Press.

— [1955], 1979. "The Ideology of Modernism." Teoksessa Solomon Maynard (toim.), Marxism and art. Essays classic and contemporary. Brighton: The Harvester Press Limited.

— [1936]. "A Great Proletarian Humanist (Funeral Speech for Gorky)." International Literature, no 8 (aug.): 8-12.

— 1934. "'Größe und Verfall" des Expressionismus." Internationale Literatur, no 1(jan./ mar.): 153-73.

Luther, Martin [1546] 1914. "Luthers Letzte Predigt zu Wittenberg." Teoksessa Martin Luthers Werke, Kritische Gesamtausgabe. Tischreden. 6 vols. Weimar: Verlag Hermann Böhlaus Nochfolger.

Macey, David 1993. The Lives of Michel Foucault. London: Hutchinson.

Malraux, André [1949], 1999. "The Conquerors." Teoksessa Hollier \& Mehlman (toim.), Literary Debate, 69-81. New York: The New Press.

— [1953], 1978. The Voices of Silence. Princeton: Princeton University Press.

Marx, Karl [1856] 1963. "Rede von Karl Marx am 14.4.1856." Teoksessa Werke, Bd.12, 3-4. Berlin.

— [1843], 1968. "Zur Kritik der Hegelschen Rechtsphilosophie." Teoksessa Werke. Berlin 1956, Band 1. Berlin.

— [1844], 1968. "Ökonomisch-philosophische Manuskripte aus dem Jahre 1844." Teoksessa Werke Bd. 40, Ergänzungsband, 1. Teil, 465-588. Berlin: Dietz Verlag.

Merlau-Ponty, Maurice [1962] 1964b. "An Unpublished text." Teoksessa The primacy of perception. Northwestern University Press.

- [1947], 2001. Humanism and terror. Boston: Beacon Press.

- [1960], 1964. "Indirect Language and the Voices of Silence." Teoksessa Signs. Illinois: Northwestern University Press.

— [1960], 1964. "Introduction." Teoksessa Signs.

— [1956], 1964. "On De-Stalinization." Teoksessa Signs. Nortwestern University Press. Evaston.

— [1955], 1973. "Sartre and Ultrabolshevism." Teoksessa Adventures of dialectic. Evaston: Northwestern University Press.

—. La Prose du monde. Paris: Gallimard, 1969.

Nancy, Jean-Luc [1966] 2007. "'André Breton,' Prose-poems on the death of Breton by
Jean-Luc Nancy." Papers of Surrealism, Issue 5 Spring 2007.

Pamphlet [1924] 1980. "Un cadavre (Anatole France)." Teoksessa José Pierre, Tracts surréalistes et déclarations collectives (1922-1969), 19-25. Le Terrain Vague.

Pico, Giovan Francesco 1496. Oratio de hominis dignitate. Editio princeps, 1496. Bologna: Benedetto Faelli.

Poster, Mark 1975. Existential Marxism in Postwar. Princeton: Princeton University Press.

Quintiliani, M. Fabi 1970, Inst. Institutionis oratoriae libri duodecim. Vols. 1 et 2, recogn. brevique adnot. critica instruxit Michael Winterbottom. Oxonii: Clarendon.

Robbe-Grillet, Alain [1963] 1996. For a New Novel. Evanston: Northwestern University Press.

Roudinesco, Elisabeth [1993], 1999. Jacques Lacan. Outline of a Life and a History of a System of Thought. New York: Polity Press.

Sartre, Jean Paul [1946], 1976. "Matérialisme et révolution." Teoksessa Situations III. Paris: Gallimard.

— [1948], 1967. Mitä kirjallisuus on? Keuruu: Otava.

— [1943], 1947. "Un nouveau mystique." Teoksessa Situations I. Essais Critiques, tekijä. Paris: Gallimard.

— [1953], 1999. "Requiem for A Poet: Mallarmé." Teoksessa Hollier \& Mehlman (toim.), Literature Debate. Text and contets. New York: The New Press.

Stalin, Josif [1938], 2010. "СТАЛИН: О ДИАЛЕКТИЧЕСКОМ И ИСТОРИЧЕСКОМ МАТЕРИАЛИЗМЕ.” Библиотека (ИНТЕРНЕТИЗДАТЕЛЬСТВО). http://www.magister.msk.ru/ library/stalin/14-19.htm (haettu 2010).

Surya, Michel 2002. Georges Bataille, An Intellectual Biography. London: Verso.

Swift, Jonathan [1726], 1953. Gulliverin retket. Helsinki: Tammi.

Tse-tung, Mao [1942] 1965. Selected Works, Volume III. Peking: Foreign Languages Press.

U.N.E.F., Strasbourg [1966] 2010. "De la misère en milieu étudiant." The Situationist International Text Library.. http://library.nothingness.org/articles/SI/ (haettu 2010).

Veyne, Paul 2007. "Je ne crois pas aux idées générales." Philosophie magazine $\mathrm{n}^{\circ} 9$, Mai.

- 1990. René Char en ses poémes. Paris: Gallimard.

Zola, Émile 1898. "J'accuse...! Lettre au Président de la République." L'Aurore, 13 janvier. 